Portland State University

PDXScholar

$1-1-1993$

\title{
Space, Consciousness, and Gender in Colette
}

William A. Parnell

Portland State University

Follow this and additional works at: https://pdxscholar.library.pdx.edu/open_access_etds Let us know how access to this document benefits you.

\section{Recommended Citation}

Parnell, William A., "Space, Consciousness, and Gender in Colette" (1993). Dissertations and Theses.

Paper 742.

https://doi.org/10.15760/etd.742

This Thesis is brought to you for free and open access. It has been accepted for inclusion in Dissertations and Theses by an authorized administrator of PDXScholar. Please contact us if we can make this document more accessible: pdxscholar@pdx.edu. 


\section{AN ABSTRACT OF THE THESIS OF William A. Parnell for the \\ Master of Arts in French presented May 5, 1993.}

Title: Space, Consciousness, and Gender in Colette.

APPROVED BY THE MEMBERS OF THE THESIS COMMITTEE:
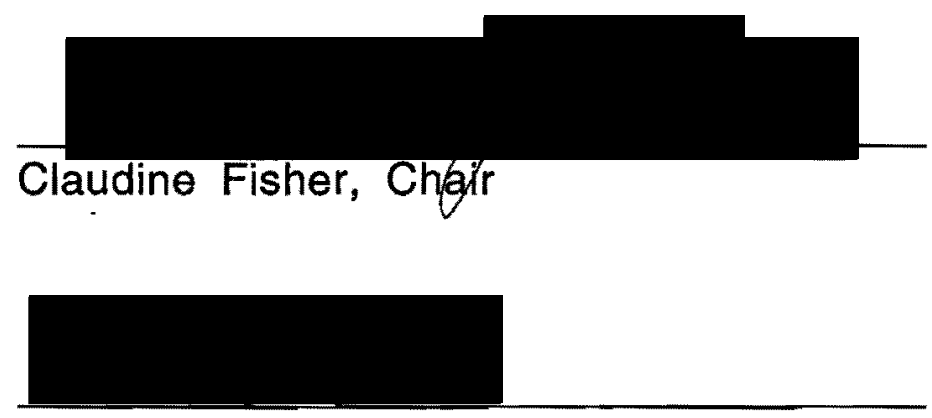

Rita R. Vistica

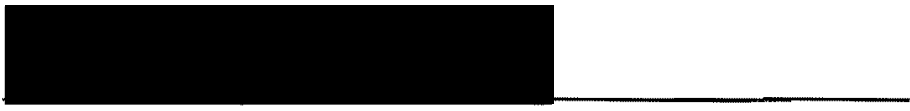

\section{Eric Swenson}

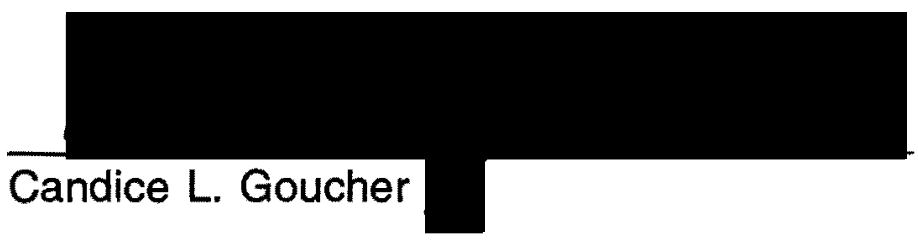

Colette's desire, to reveal the different levels of difficulties in relationships, results in the creation of three masterpieces, Le Blé en Herbe, La Chatte, and La Vagabonde. Through her characters in these novels, the author exposes the spatial boundaries set by each 
couple. Also, she concentrates on the maturation of the protagonists. The woman's function in society transforms as she gains personal power, and she becomes self-reliant. Finally, Colette evades sexual stereotyping by introducing the reader to the issues of gender and androgyny. She helps to dispel the sexual myths around the idea of normal stereotyping. Themes such as male and female physical characteristics and related "socially acceptable" behaviors are addressed. In general, these works clarify ideas about the way in which individuals associate with one other.

Chapter I will analyze the spatial limitations created by the protagonists. It will examine two binary oppositions, "in/out" and "dream-world/reality". The "in/out" opposition will focus on both physical and mental spaces, whereas the "dream-world/reality" opposition will magnify tangible and unreal spaces. This chapter's objective is to demonstrate the uses of territorial boundaries and deduce their affects in relationships.

Chapter II will investigate the association between Colette's characters and the liberation of womankind. The aim is to examine the female characters' growth in regard to the society around her. As well, obtaining personal power and the concept of empowerment is treated by studying the use of the female voice. This chapter will show a recurring theme of women overcoming the forces of patriarchy and moving beyond the confines of societal rules.

Chapter III will study the issue of gender and androgyny in Colette's characters. It will bring to light Colette's use of gender roles, and the way in which her protagonists search out an identity 
and learn about themselves. Finally, this chapter will cover gender stereotypes and Colette's contemporary view of such an issue.

In summary, the novels to be treated, Le Blé en Herbe, La Chatte, and La Vagabonde, will move through three different levels of development in the growth of the characters, from adolescence through young adulthood and into maturity. This notion will be utilized in each chapter and will demonstrate Colette's theme of relationships which spirals out of three connected ideas, space, consciousness and gender. 


\title{
SPACE, CONSCIOUSNESS, AND GENDER IN COLETTE
}

\author{
by
}

WILLIAM A. PARNELL

A thesis submitted in partial fulfillment of the requirements for the degree of

\section{MASTER OF ARTS}

in

FRENCH

Portland State University

1993 
TO THE OFFICE OF GRADUATE STUDIES:

The members of the Committe approve the thesis of William A. Parnell presented May 5, 1993.
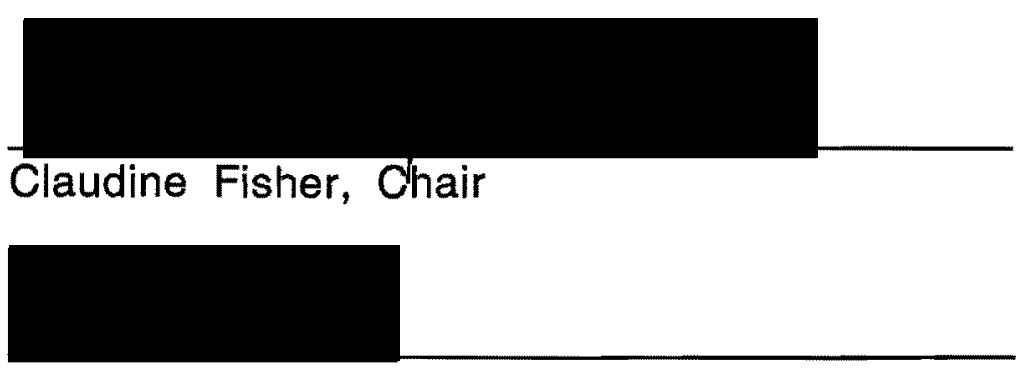

Rita R. Vistica

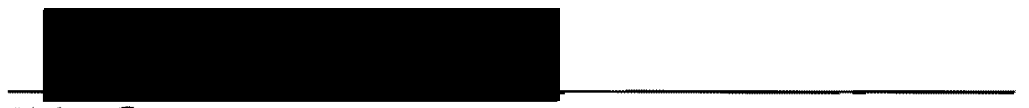

Eric Swenson

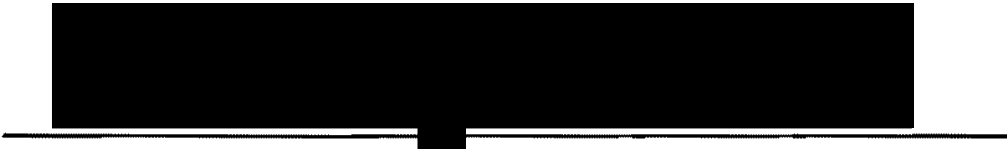

Candice L. Goucher

\section{APPROVED:}

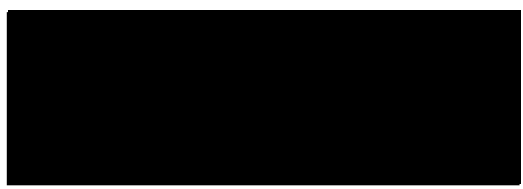

Linda B. Parshall, Chair, Department of Foreign Languages and Litaraturac

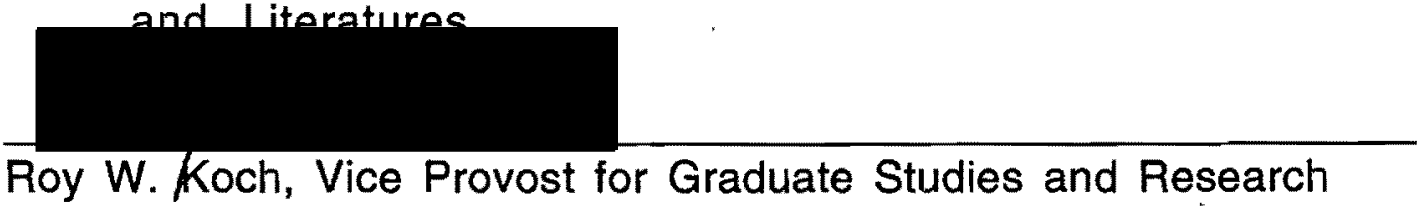




\section{ACKNOWLEDGEMENTS}

I would like to thank Claudine Fisher for her diligence, kind words, and enthusiasm, without which this thesis could not have been written. I am grateful to my good friends, Rachel and David, and my mother for having read and discussed parts of my work in progress. I am particularly appreciative of the great work Colette produced. This has allowed me to discover a successful pathway in finding myself and in finding a greater sense of personal power. 


\section{TABLE OF CONTENTS}

PAGE

ACKNOWLEDGEMENTS.

$\mathrm{i} i \mathrm{i}$

CHAPTER

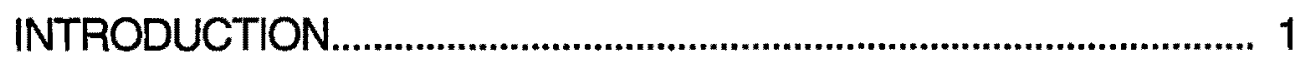

I SPATIAL BOUNDARIES................................................. 8

In/Out Binary Oppositions................................... 8

Dream-World/Reality Oppositions..................... 25

॥ FEMININE CONSCIOUSNESS.......................................... 39

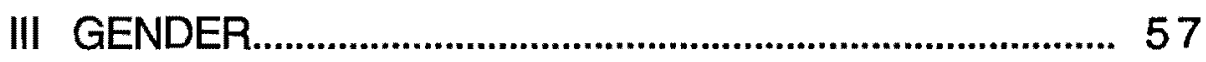

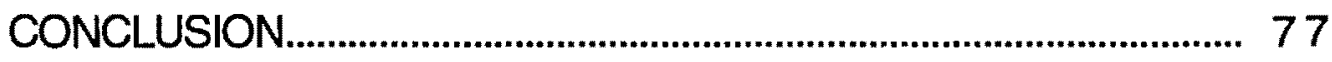

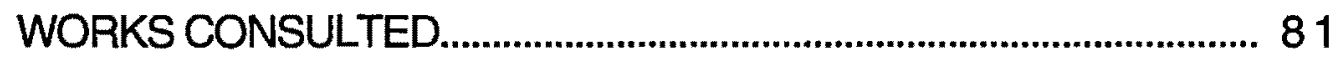




\section{INTRODUCTION}

Colette, a well-known author of the early twentieth century, a woman writing about womankind, gained part of her fame when readers learned that her husband locked her in a room and forced her to write under his name. It was only later, when she left the marriage, that she discovered her own power; and from this earlier labored form of expression, she bloomed into a full-fledged writer. Colette demonstrated aptitude at communicating about relationships of various levels. She transcended the thought of her own age and helped to bring about new philosophies. She was a humble writer who spoke little of her own writings in a time when many others were theorizing about what they themselves had written. Even after sixty years of writing, Colette still evaded literary criticism about her own works (Evans, 37). Her words, springing from her individual prism of consciousness, carried circular themes and particular motifs which impressed the reader. Her ideas reached a level of importance beyond the norm, considering she wrote between the years of 1900 and 1954 . They revealed a basic human level of interaction, not as specific as "tropisms" encountered in Sarraute's writing, a woman writer from the following generation, but similar in their effects and affects. Her themes revolved around the coming together of two individuals, their reactions towards each other and a final departure. Three masterpieces which will be studied, Le Blé 
en Herbe (1923), La Chatte (1933), and La Vagabonde (1910), each represent the theme of connection, growth and departure between humans. In addition, they creatively reveal bits of the "real" Colette to the reader.

Colette, born under the name Sidonie-Gabrielle in 1873, compiled an entire life's work comprising her "Claudine" novels to $L e$ Fanal Bleu. Colette married at the age of twenty to a much older man named Henri Gouthier-Villars, who "introduced her to the enervating decadence of the Paris demimonde" (Phelps, 114). He made her record on paper the memories of her childhood and school years, a time when she lived with her mother in the countryside of the French Burgundy region. When she freed herself from this disastrous marriage with Henri, nicknamed 'Willy', she became a music hall dancer, at which time, she began to document her thoughts and seriously embark on a literary career. Later in her life she became a well-known author. "Having gained the respect of her contemporaries, she was elected to the prestigious Académie Royale Belge and Académie Goncourt" (Phelps, 114).

Colette's life experiences are represented throughout her novels. Freud alludes to the fact that all writing comes from the creator of the words, thus adjoining the past actions, the present thoughts and the future dreams of the author which would all be represented by his or her voice. "Freud suggests that all fiction is auto-biographical, reflecting the writer's experience, and haunted by shades of the writer's past" (Flieger, preface ix). A perfect example of this is Le Blé en Herbe. It presents a story which depicts an 
adolescent couple with interpersonal struggles. The young female character, Vinca, is in love with her life-time best friend, Phil. He is interested in an older woman and hides this from Vinca. Their relationship breaks down because of his secret affair, and her intuitive ability to anticipate his actions. They labor over their feelings towards each other; Vinca finally gives in to Phil's power and sleeps with him, then decides to continue their relationship. This choice marks the resolution and closure of the story.

Another work of fiction that is permeated with a great sense of reality is her masterpiece La Chatte. It reveals the challenges of young adulthood through its main protagonists Camille and Alain. The story presents the reader with the concept of married life between two persons of different backgrounds, neither of whom wishes to concede failure nor make compromises necessary to adapt to their new life together. An atypical love triangle forms between Alain, Saha and his new wife Camille. It is atypical since Saha happens to be a cat. Camille tries to kill Saha and when Alain discovers this, he leaves her and returns to the cat and his mother's home. Camille prefers, naturally, at this point, to embark on a new journey in life and leave Alain.

Lastly, one of the most important pieces of work put together by Colette is La Vagabonde. Early in her career, she creates another masterpiece which tackles the issue of self-discovery. The basic story line remains similar to the others, with one major exception. The struggles and periods of growth for Renée, the main character, have much less to do with the secondary character, Max, than in the 
other novels. They reflect Renée's development toward a peaceful wholeness within her own spirit.

With La Vagabonde...she was able to confront her themes more squarely, drawing upon her own experience, by creating a character whose story is self-contained, and sufficiently distanced from autobiography that is can be told without the sometimes uncomfortable 'holes' of the Claudine novels. (King, 70)

Colette allows for Renée and Max to come together for a short period of time; but eventually their tie is severed when Renée flees from the bondage of the patriarchal world represented by Max.

Many other novels by Colette contain concepts related to those already mentioned. It is important to note that these three novels, Le Blé en Herbe, La Chatte and La Vagabonde have several common themes but will be treated at different stages of the protagonists' development. The characters shift in personal evolution; from adolescence, through young adulthood, to maturity.

Initially, Chapter I will study territorial and spatial boundaries and will use binary oppositions in its examination. The definition of a binary opposition is best given by C.K. Ogden: "When two terms 'express the greatest degree of difference possible,' in the same universe they are called contraries" (Ogden, 55). These contraries are derived from a central axis and create opposite meanings.

Opposites...may be either the two extremes of a scale or the two sides of a cut; the cut marking the point of neutrality, the absence of either of the two opposed characters in the field of opposition. (Ogden, 58) 
In order to further explain Ogden's theory, Kadish offers a similar use of binary opposition to her literary study of Gide. She uses Greimas' methodology to expound on her point.

Greimas' procedure for accounting for the semantics of literature, one will perhaps recall, entails establishing a complete system of meaning from a pair of opposed semes- for example the semes life and death.... (Kadish, 384)

Consequently, to summarize this chapter's focus, we will call upon two major categories of opposites; "in/out" and "dream world/reality".

The two levels of oppositions are sub-treatments of a larger concept presented in Colette's works. Spatial boundaries are a main theme recurring throughout her novels. It can be an issue of physical, mental, tangible or unreal space. The physical and mental space will be closely examined in the "in/out" binary opposition, whereas the tangible and unreal space will grow out of a study of the "reality/dream world" opposition. The treatment of space in her story is simply one of conflict and denouement.

Chapter II will primarily focus on the growing feminine consciousness of the female characters and the causes linked to their growth. These include Freudian psychoanalysis, the increased awareness of male patriarchy, and a budding intellectual awareness which carries these women through their "rite of passage" into freedom and liberty.

In this chapter, the female voice is considered because when it is appropriately used, it creates power. This voice is represented by 
either silence or talk. Secondly, self-awareness in the female character is studied and it comes about through her discovery of the natural world and the patriarchal society. She recognizes a need to be freed from the bondage of traditional society and therefore, she reaches for freedom by taking back some kind of power.

Chapter III investigates Colette's treatment of gender. Her main characters, in each of the three novels, all probe issues dealing with gender roles. In Le Blé en Herbe the identification of masculine and feminine roles is somewhat confusing for the two teenagers. They fluctuate between the two poles. In La Chatte, the main characters are at opposite ends of the spectrum of what is socially accepted as masculine and feminine roles. They are in a state of role reversal. Finally, in La Vagabonde the female protagonist is moving towards an understanding of herself and her androgynous nature or behavior.

Colette does not stick to the stereotypical norms of masculine and feminine behavior in her writings. She ventures out and searches for a truly whole being.

Colette is the chief, after Proust perhaps the only, modern French figure who is marvelously androgynous, open before all experience, loving nature with a reciprocity that is unique in an individual who can write brilliantly of that love. (Heilbrun, 87)

Her characters make certain decisions which affect the way they behave. The characters do not allow the inner working of society to dictate how they will react. However, they do have to fight against the normative thoughts projected out by society. 
Against the backdrop of the socially created forms of masculinity and femininity, all of us play out our lives. If the forms indeed determine our behavior, have we no choice in guiding our own destinies? Must we succumb to that which is already predetermined? Numerous social scientists answer with a resounding "No!" (Forisha, 82)

Colette portrays gender on two different levels. For her it is a biological and sociological issue. It manifests itself on the biological plane through physical characteristics, and on the sociological plane through emotional and mental reactions. Chapter III will determine how the characters will interact in their relationships with others or with themselves, while moving from androgynous confusion to a sense of well-being and peace.

In conclusion, the themes and motifs exhibited in Colette's writings all circle back to a main concept. The idea of relationships and personal development prevails over all other thought in her works. Again, each of the three novels, Le Blé en Herbe, La Chatte, and La Vagabonde, maintain their own level of maturation in terms of the characters involved in the story. So, even in Colette's fiction there lies a grain of truth about the evolution of life, especially for that of the modern woman. Human compassion has been unveiled with the help of Colette and "by insisting on being human, she became a heroine" (Evans, 74). 


\section{CHAPTER I}

\section{SPATIAL BOUNDARIES}

In three novels by Colette, Le Blé en Herbe, La Chatte, and La Vagabonde, the connection between Colette's protagonists lies heavily in the way they define their personal boundaries. The territorial mark that they create, either through physical or mental means, takes its form in opposites. Thus, the two binary opposites to be studied are "in/out" and "dream-world/reality". Again, the confines devised, which guide the movements of the protagonists, give credibility to the ultimate decisions each makes in terms of strengthening or crippling a relationship.

\section{IN/OUT BINARY OPPOSITIONS}

Territorial and spatial boundaries have an important place in Colette's three novels. These boundaries come into clearer focus thanks to the use of binary oppositions. The first spatial and territorial boundary enhances the "in/out" concept, that of both physical and mental spaces. In Le Blé en Herbe, the different types of space to be treated include the space around Mme. Dalleray, the "beach" space, the "cliff" space, and the inward space. Although it appears in Le Blé en Herbe that the two main characters, Phil and Vinca, share each other's space, it will be pointed out that they 
ultimately do not. There is a commonality between Vinca and Phil's outward space but as soon as Phil encounters Mme. Dalleray, the structure of Vinca's physical spaces and his own shifts. Phil's space with Mme. Dalleray is a secret from Vinca, and therefore outside of Vinca's space. "En bas de la plage déclive, parmi les feux de cent petits miroirs d'eau d'où rejaillissait le soleil, un béret de laine bleue...marquait la place où Vinca, obstinée, cherchait encore..." (Le Blé, 51). While Vinca is down below on the beach, Phil, who is on the cliff, meets and talks with Mme. Dalleray. Afterwards, when Vinca asks about this meeting, Phil becomes evasive, and keeps Vinca out of the personal space he shares with Mme. Dalleray.

Et pourquoi est-ce qu'elle est partie si vite, juste au moment où je venais?...Il rêva un moment et trouva une réponse ambiguë qui satisfaisait en même temps son goût de secret romanesque et sa pudibonderie de jeune bourgeois.... (Le Blé, 55)

Phil keeps his secret from Vinca which continues to widen the spatial gap between them, all the while interacting with Mme. Dalleray. On his way to a secret rendez-vous with this new woman, Phil realizes that he is deceiving Vinca but scoffs at this realization.

$\ll$ J'aurais dû emmener Vinca, ricana-t-il. Quelle musiquel $>$ mais un autre Philippe, en lui, le Philippe épris de Vinca, le Philippe enfermé dans son précoce amour comme un prince orphelin dans un palais trop vaste, répliqua au méchant Philippe : « Tu l'aurais portée sur ton dos jusqu'à la villa, si elle s'était plainte...>. (Le Blé, 80) 
Phil discovers that this space is now his own territory and cannot be shared with Vinca.

Vinca dares to regain Phil's affections the morning after his escapade with his secret lover. She invites him down to the water, commonly used as her space, a place where she has always had fun since childhood. "Les rires reprirent en bas...Viens te baigner!" (Le Blé, 109). Vinca wants Phil to grasp her feelings of love and let go of his secret mistress: In essence, she denies the change in their spatial conflict and asks to return to a time when her life was not complicated. "Phil je crois bien que j'aimerais retourner en arrière et redevenir enfant aujourd'hui..." (Le Blé, 120) She soon realizes the impossibility of her request and instead confronts Phil about his outside space. "-Me faire le récit de vos amours, n'est pas? Pas la peine. Mercredi dernier quand tu es rentré, j'étais levée sans lumière...Je t'ai vu...comme un voleur..." (Le Blé, 155). This confrontation does begin to put back into place their space by clearing the air; however, it does not change their feelings, which is to say that their problems go unresolved. Vinca still desires Phil but is cautious about demonstrating her feelings, whereas Phil is still infatuated with Mme Dalleray. On the whole, they start to share physical/external space again, although psychologically their internal space does not allow them to fully regain confidence, as seen projected onto their territory and its boundaries.

Again Phil's and Vinca's external space (physical) creates barriers as manifested by their internal space (mental). They each have an inward, private territory where the other does not enter. 
Phil's moments of privacy, which occur in what can be termed, narratively speaking, as a 'stream of consciousness', divulge information to the reader but not to Vinca. Colette uses this internal dialogue to show Phil's emotions about Vinca as well as about his life. "Encore quelque jours, se dit Philippe, et nous nous serons séparés" (Le Blé en Herbe, 62). It is through his inner thoughts displayed in the text that Vinca is kept out of his space. He does not share with her these thoughts, so she feels left out, and starts accusing him:

-Tu ne m'aimes pas assez, Phil, tu ne m'aimes pas assez! II voulut parler, et se tut, car il n'avait pas de noble aveu à lui faire. II rougit et baissa la tête, coupable d'avoir -- alors qu'elle glissait vers le lieu où l'amour ne tourmente plus, avant le temps, ses victimes -- traité son amie comme l'épave précieuse et scellée dont le secret seul importe, et refusé Vinca à la mort. (le Blé en Herbe, 64)

This secrecy causes a break down in their communication as friends and lovers. "-Le petit garçon te (Phil) cherchait, il m'a rencontrée et m'a informée la première...Ah, alors (Vinca) tu savais...Qu'est-ce que tu savais?-Des choses sur toi (Phil)..." (Le Blé, 154). Vinca now discovers Phil's secret which tells her indirectly that she truly does not share space with him, and that he has an outside space separate from her.

Because of Phil's secrets, the inward space is not shared. Phil continues to distanciate Vinca from him, creating a gap between them, leaving more distrust in Vinca's mind and more freedom and thrill in Phil's. "Cette visite, qu'il a caché à Vinca, formait dans sa 
mémoire un point battant et sensible..." (Le Blé, 87). Vinca feels this blockage between them.

Mais la pureté vigilante de Vinca percevait, par des avertissements soudains, une présence féminine auprès de Philippe. II arrivait qu'elle flairât l'air, autour de lui, comme s'il eût, en secret, fumé, ou mangé une friandaise. Elle interrompait leurs causeries par un silence aussi impérieux qu'un bond, par un regard dont il sentait le choc et le poids. (Le Blé, 96)

Vinca senses "an air" around Phil. At this point she becomes reclusive, and finds her own private inward space. Phil comes back from his evening at Mme Daleray's and he sits outside, "s'appuyant à la barrière blanche", while Vinca tries to sleep inside. "Elle ne dort pas. Elle vient de regarder l'heure. Pourquoi ne dort-elle pas?" (Le Blé, 106). Vinca's silence creates her internal space not only in the bedroom but also in her mind. Phil does not enter the bedroom which is a physical barrier nor does he comprehend what Vinca is feeling; hence their mental barrier. Even though Phil and Vinca have shared their physical space for a long time, this blockage suddenly tears away their contrived attitude to bring forth the intuitive force which links them.

La vie de Philippe appartenait toujours à Vinca, à la petite amie de son coeur, née tout près de lui, douze mois après lui, attachée à lui comme une jumelle à son frère jumeau, anxieuse comme une amante qui doit demain perdre son amant. (Le Blé, 87)

However, Vinca's feelings become practically irrelevant to Phil, he believes that he has moved into his own space, separate from 
Vinca's. In watching her, he notices her body and decides that he will never sexually be with her. "Qu'y avait-il de commun entre ce corps, entre l'emploi que l'amour en pourait faire, entre ses fins inévitables....Jamais! dit-il à voix haute...Jamais!" (Le Blé, 106). Sex, as the ultimate in shared space, which is now denied by Phil, causes a breakdown in the shared territory, as they move from childhood to puberty and into adulthood.

The final "in/out" space which happens to be shared physically by Vinca and Phil is clearly symbolic; this space is on the threshold of the outside and the inside, that is to say at the edge of the open window. Phil leaves his window open one night and Vinca calls to him to come outside. The open window is like a link between the in and out space. "C'est toi Phil? la voix descendit jusqu'à lui...ll se leva, marcha sans bruit jusqu'à la fenêtre..." (Le Blé,177). This same phenomenon appears again in La Chatte, when the female protagonist, Camille, talks of a coming storm. In the midst of it she leaves the windows open, letting the outside rain and wind come inside. Meshing both inside and outside, she dares bring the two together.

Par les baies ouvertes la pluie entra comme ils s'apaisaient, tiède et cinglant embaumée d'ozone. Aux bras d'Alain, Camille lui faisait comprendre qu'elle eût voulu.... (La Chatte, 75)

In both stories the window is like a border that the characters have to cross. The female protagonist is the one to call her male partner to "cross". 
In Le Blé en Herbe Phil does cross this barrier when he follows Vinca. They go away from the house to their secret place near the beach, and find themselves embracing, pondering all the while their issues of boundaries; how much they should show their emotions; how far they should go; and how long they should take. This is an indication that their spatial boundaries are not stable and that they have truly moved away from one another because of this fluctuation. "Il secouait la tête pour s'en délivrer, et Vinca, croyant que Philippe voulait rompre leur baiser, serrait davantage." (Le Blé, 182) It appears that Vinca, like the other females in Colette's writing, desires to enter Phil's space. He guards against her, in effect pushing her outside of his territory, even when they embrace and kiss. Vinca does not give up the struggle of defining her spatial limitations with Phil and the the novel ends in encouragement that they will persevere.

One of the more obvious oppositions in La Chatte is the distinction in character between Camille and Alain. It leads the reader directly to the "in/out" spatial conflict. Alain represents the traditional patriarchal family values, whereas Camille portrays the modern, high-energy independent female. Their social class is divided as well:

II se leva du banc vert, pris le sourire important du fils Amparat qui épouse, condescendant, la petite des essoreuses Malmert, une jeune fille qui n'est pas tout à fait de notre bord" disait Mme. Amparat. (La Chatte, 37) 
Alain reveals a typical, condescending attitude towards a lowerclass group than his own social stratum. It sets apart Camille and Alain at first glance, but delving deeper into their particular situation, the external space will shape and determine the entirety of their relationship.

Alain's family house where the young couple were supposed to live is not finished so Camille, meanwhile, proposes a solution to their housing problem by asking to move elsewhere, thus out of Alain's space.

Ça (la maison) n'avance pas! Ça ne sera jamais fini(e)... si on était malins, on le garderait pour nous, le studio de Patrick. Patrick s'en refera un autre. Je m'en occupe, si tu veux? (La Chatte, 13)

This Quart-de-Brie studio, soon to be Camille's, Alain's, and Saha's apartment, is in town, is much smaller than Alain' house, and is more befitting of Camille's style. The traditional house however depicts much the opposite.

Depuis la naissance d'Alain la maison avait peu changée. "Une maison de fils unique", estimait Camille qui ne cachait pas son dédain pour le toit en gâteau, pour les fenêtres du haut engagées dans l'ardoise, et de certaines pâtisseries modestes aux flancs des portes-fenêtres du rez-du-chaussée. (La Chatte, 11)

This picture of a big, overdone aristocratic house versus the small modern art-déco studio, is the first in a series of the division of "in/out" space; "in" being Alain's house and "out" being Camille's studio. As Mariana Forde points out in her critical article of $\mathrm{La}$ 
Chatte, "A dominant theme shaping the plot is the search for and defense of space" (Forde, 361).

Although Camille and Alain are to be married, the future union appears to be agreeable mainly to Camille. Alain wishes to destroy their arrangement. "Le mariage ne fait que confirmer chez Alain le léger écoeurement qu'il éprouve en présence de l'exubérante Camille" (Abstract of La Chatte). Camille constantly searches for Alain's private space so she can penetrate it in order to win his love. However, Alain wants no part of her love, and pushes her further away by bringing Saha into their new apartment and into Camille's territory.

If this makes a triangle in the character structure, the basic spatial structure is nevertheless binary. Except for her jumping and other motions, Saha does not have her own space but shares all of Alain's spaces. (Forde, 367)

Saha and Alain share one space while Camille yearns to enter it but cannot because of Alain's passive resistance.

The encompassing "in/out" opposition by which the spatial polarity is already established often fluctuates to reverse itself for both main characters in La chatte. The alliance between Alain and Camille is Alain's attempt to break from the mother, her house and his traditional background even though this represents his security. His comfort lies within his mother's home and the garden of his childhood. Just before Alain goes to bed in his mother's house the reader begins to understand his comfort zone as a recapturing of his adolescent years. "II redevenait faible, chimérique, attardé dans les 
rets d'une interminable et douce adolescence" (La Chatte, 22). He then is vexed at the possibility that Camille could be replacing his old comforts inside of his house.

Dans sept jours, sept nuits, une vie nouvelle, dans un gîte nouveau, avec une jeune femme amoureuse et indomptée... II caressa le pelage de la chatte, chaud et frais, fleurant le buis taillé, le thuya, le gazon bien nourri. Elle ronronnait à la pleine gorge, et dans l'ombre elle lui donna un baiser de chat, posant son nex humide, un instant, sous le nex d'Alain, entre les narines et la lèvre. Baiser immatériel, rapide, et qu'elle n'accordait que rarement...

-- Ah! Saha, nos nuits.... (La Chatte, 22)

The marriage vows show that Alain tries to break away from tradition, and move away from his mother's ties. In effect, the marriage will lead only to eventual failure. It also points out Alain's lack of openness towards change, mostly in space. The style uses many directional prepositions such as, 'dans' and 'avec' which remove Alain's decision-making responsibility from center stage. "As a ruthless outsider, Camille is unencumbered by tradition. The text shows her often creating her own space" (Forde,367). Camille is definitely on the outside, prefering the open spaces and the open road. "-Savoir si on l'aura, la voiture, le mignon roadster..." (La Chatte, 8).

Camille wants a fast car from the beginning, a vehicle of liberation, of leaving, which will take her away or "out". Secondly, she decides that they would stay at Patrick's "Quart-de-Brie", which. is also outside of the family and tradition. Camille's desire to traverse Alain's space and awaken his feeling of love starts at 
the point of the story when Camille opens the bay windows. Here, she creates a link between the in and out spatial barrier. She tries to join Alain's space with hers. This attempt and her plea do not work.

Son souhait fut si affamé que le murmure du vieux calorifère mal réglé suivit l'évocation des bouquets plats et clairs, murmure et haleine de cave sèche, issue d'une bouche à lèvres de cuivre, encastrée dans le parquet. (La Chatte,75)

She tries another route. Sexual affection does not work either, since Alain abhors being touched on the face. "Je n'aime pas qu'on me touche la figure. Le reste ne te suffit pas? Ne me touche jamais la figure." (La Chatte, 77). Camille realizes that she will never enter inside Alain's space. Ironically enough, always being on the outside, she discovers the true reason why.

Alain allows Saha to control his space. For this reason, Camille tries to kill her. "Camille's attempt on Saha's life is a desperate attempt to reach Alain" (Forde, 367). Camille throws or slightly bumps the cat off of the balcony ledge, in order to knock the cat out of Alain's space by killing the cat. "Camille n'aimait pas ce balcon-terrasse réservé à la chatte..." (La Chatte, 111). The boundaries of "in" and "out" being set, and the cat moving into the "Quart-de-Brie", into Camille's outside territory, Camille charges towards her destiny.

Saha sentit chanceler la fermeté de son ennemie, hésita sur le parapet, et Camille tendant les deux bras, la poussa dans le vide.

Elle eut le temps d'entendre le crissement des grilles 
sur le torchis, de voir le corps blue de Saha tordu en $\mathrm{S}$, agrippé à l'air avec une force ascendante de truite, puis elle recula et s'accota au mur. (La Chatte, 114)

Camille wants to kill the cat but fails. At this point, Camille has brought to a head her territorial problems with Saha and Alain. The couple becomes motionless in the space at the "Quart-de-Brie". "II avait surgi de l'ombre tous deux comme deux statues, Camille en marbre lilas, Alain plus blanc, les cheveux verdâtres et les prunelles décolorées." (La Chatte, 125). The two, transformed into marble statues, argue on each side of the bed; and Alain finally makes his long awaited decision of retreat back to his 'womb-like existence'. "Voilà, je m'en vais, répéta Alain... Nous nous en allons" (La Chatte, 133). He lets Camille know that the end has come, that he would now entirely remove himself from her space and retreat inwardly. Back in his comfortable space at home, Alain rests and finalizes his plan to separate. In his comfort zone, he does not even deliberate over his problem. He just resumes his old habit to continue life as usual until Camille comes back to confront the issue, and to finalize their plans to seperate.

The last "in/out" occurrence is formulated at Alain's family home. Camille comes for a brief exchange of words, which mark the last separation of the story. Before she enters, Alain asks one of the housekeepers if she had opened the door for Camille's entrance. "-Vous avez ouvert, au moins?"(La Chatte, 150). This lets the reader know that Alain is back in charge within his own space. “...Alain s'avança à sa rencontre. Car il approchait sans se détacher 
de son atmosphère protectrice, foulait le gazon natal..." (La Chatte, 150). He is at last back 'in' his comfort zone walking on his "natal" lawn. The grand finale is Camille's exit. "Elle s'en allait...Seul, il s'effondra dans un fauteuil et près de lui...la chatte" (La Chatte, 158). Camille leaves behind Alain and his cat, but most of all, she escapes from the space in Alain's heart that he had created for the cat.

Colette's first 'chef-d'oeuvre', La Vagabonde, appears to contain many similar spatial conflicts which are found in her other works. However, these conflicts no longer include a two female-one male love triangle: This story is more clearly based on a one female-one male relationship, with a mother figure (from a distance) and the memories of an ex-husband invading their space.

On the surface, La Vagabonde recounts the dilema of the recently divorced Renée Neré who maintains her independence by working as a mime in a music hall, yet at the price of almost unbearable solitude. In fact, the novel describes the struggle for control of Renée's existence. The conditions of her existence are inextricably bound to the spaces she inhabits.... (Cothran,27)

Colette divides the spaces of this book once again through "in/out" spatial boundaries. These spaces include the dressing room, the dance floor of the performance hall, her house, and the countryside where she eventually travels with her troop (Cothran, 28). At first, Renée is preoccupied with her relationship to the self. She displays this through her isolation in her house and in the dressing room. 
Comme d'habitude, c'est avec un grand soupir que je referme derrière moi la porte de mon rez-de-chaussée.

Soupir de fatigue, de détente, de soulagement, ou l'angoisse de la solitude? (La Vagabonde, 12)

Renée's internal space of solitude parallels the description of her house. "Ma maison elle-même, toute seule dans la rue, a $\ll$ l'air que ce n'est pas vrai>>" (Vagabonde, 11). This holds true for her dressing room as well. Her friends visit her there, however Max, her soon to be lover, once tried to enter this space and he is made to leave. "Je vous dirai donc gentiment, monsieur, ce que je vous aurais dit sans aménité: allez-vous-en! Je ris, bonne fille, en lui montrant la porte..." (Vagabonde, 24). After Renée's need to explain the frequent reoccurence of anonymous men arriving at her doorstep, she retreats deeper into her mind. She then, relates and compares her external life to a house in the forest. "Une maison paisible au milieu des bois?" (Vagabonde, 26). Renée links herself to a space of refuge, a space where she would no longer need hide from men, or more specifically from the memories of her ex-husband.

Ironically, Renée is invited to perform at a "danse-hall" in her old community of friends, which she had with her ex-husband. She accepts the idea that her space on the dance floor as well as the act of dancing would become her sanctuary or protection. No one could hurt or touch her there. The outward physical display of dancing, even though she believes she is safe, does not protect her from intruders. She meets a man who soon becomes her lover. This man, Max, is slowly admitted in Renée's territory. On the other side of the music hall he first appears. "Au fond du salon, une silhouette 
d'homme gesticule et crie..." (vagabonde, 54). This man slowly begins to break through each of Renée's private barriers until she is forced to make a final decision; to reclaim her territory or to share it with him. First, he makes his presence known in her dressing room through small gifts and flowers. "...et je reste seule avec ma gerbe de roses, une grande gerbe banale...c'est bien la gerbe d'un <grand serin>> tel que mon nouvel amoureux!" (Vagabonde, 63). Renée begins to recognise Max' invasion of her space. "Et puis, il y a cet homme -le Grand-Serin- qui s'arrange pour vivre dans mon ombre, pour mettre ses pas dans l'empreinte des miens..." (Vagabonde, 69). When Renée is not in her safe territory, she becomes extremely threatened by Max, and loses all sense of her own power.

Dans la rue, je croise, trop souvent, le même DuffereinChantel, qui me salue avec une surprise si mal imitée... II me force à me rappeler, trop souvent, que le désir existe.... (Vagabonde, 70)

Renée has pushed all desire out of her space after her divorce with Adolphe Taillandy. Now, Max's desire for Renée envelops her physical space until it finally reaches and touches her body.

Je regarde, étonnée, cet homme qui a réussi à pénétrer chez moi. Parbleu! il le voulait tellement!...le moyen de jeeter dehors cet individu attendant gauchement, les bras chargés de roses, à côté d'Hamond qui m'implorait du regard? II a réussi à pénétrer ici.... (Vagabonde, 87)

Renée can neither quite forget her past nor give into this desire, because she has tried to block it out with the memories of her exhusband. "...le regard...la poignée de main...de mon amoureux me 
rappellent pourquoi il est là et ce qu'il espère...et surtout. Oh! Surtout! le souvenir de mon mari..." (Vagabonde, 92). Renée senses the pressure of having to succomb to this physical desire with Max. However, she discovers a possible way out.

Brague, her dance partner, proposes that they go on dance tour and Renée accepts. Her decision to leave occurs at a moment when she is searching for the right answer from signs in nature. It begins to rain, washing away the residue from the streets; Renée looks about her, and decides that nothing is keeping her in Paris. As in Le Blé en Herbe and La Chatte, Colette uses the rain as a release or sign from nature of a future cleansing of her space by leaving Max behind. Renée watches the small storm clean the streets and takes her freedom that the tour will provide.

Rien ne te retient?... Une courte pluie, presque orageuse, a commencé le dégel; le pavé noirâtre reflète, étirées, frisées, les lumières. Le haut de l'avenue se perd dans une fumée indistincte, roussie par un reste de crépuscule... Involontairement, je me retourne, je regarde autour de moi, cherchant...quoi? Rien, Non, rien ne me retient ici, ni ailleurs. (Vagabonde, 111)

After this decision to leave, Renée becomes careless with her physical space, since she will soon depart from Paris. She becomes more vulnerable to the constant presence of Max.

Graduellement elle s'habitue à lui, et quarante jours avant son départ en tournée théâtrale, elle se laisse aller à être naturelle devant lui. Elle est si sûre alors de dominer la situation, puisque son départ est si proche. C'est là où elle commet son erreur. (Fisher, 214) 
Her 'mistake' leaves her but one choice, which is to depart, and hopefully find her own space and freedom again.

Renée does escape thanks to the freedom of the French countryside. Nature becomes a solace for Colette's protagonist. This outside territory, away from Max's influence focuses Renée onto her own feelings, and readjusts her space so she may clearly convey her need for freedom.

Adieu, mon chéri. Cherchez loin de moi la jeunesse. la fraîche beauté intacte, la foi en l'avenir et en vousmême, l'amour, enfin. tel que vous le méritez, tel que j'aurais pu autrefois vous le donner. Ne me cherchez pas. J'ai juste la force de vous fuir. (Vagabonde,246)

This new place, the countryside, linking Renée to her childhood, and recreating some of the forcefulness of her youthful character (such as Vinca), gives her the strength to cut her tie to Max. Even when his power over her increases as he proposes marriage to her, she decides to remain alone.

The journey, through the French countryside gives her access to the natural world, progressively restoring her to her own space... First crossing Renée's (and Colette's) native Burgundy, the tour then takes her to her "refuge élyséen", the gardens in Nîmes, and finally brings her to the limitless expanse of the sea. (Cothran, 32)

The sea of Renée's childhood is where Vinca's story in Le Blé en Herbe is recounted. This youthful space overpowers Max's earlier invasions of Renée's space, and helps bring to a close the different elements of "in/out" territorial boundaries. Renée's life circles lead 
to the inevitable conclusion of being free but alone and erring as the "Vagabonde".

\section{DREAM-WORLD/REALITY OPPOSITIONS}

Another important opposition touching these stories relates to the theme of the world of reality and the dream-world. Colette's interpretations of the female characters through the dream-world of the male characters can be related to the metaphors of the evil eye', that of 'birds' with a main focus on the white dove, and that of other creatures, like shellfish and the canary. A blanket of darkness and shadows seem to cover them all. In Le Blé en Herbe, La Chatte and La Vagabonde reality seems apparent while the dream world is obscure, represented by another dimension. Images can be found in alternate spaces such as in the mirror or in the dream state. Scott Cummingham exemplifies the shift in dimensions between the real world and the dream world.

Dreams are often perceived to be irrational or fantastic precisely because they aren't under the control of the conscious mind. The dream-state isn't limited by time or space; it operates within an alternate reality. (Cunningham,16)

In Le Blé en Herbe Phil has many visions which he does not decipher. Yet these visions are important to the reader who can interpret each one. "Mais le rêve, ni le cauchemar ne dépendent de la vie réelle. Un mauvais rêve, riche d'ombre glaciale, de rouge sourde, de velours noir et or, empiétait sur la vie de Phil..." (Le Blé, 88). This dream 
doesn't awaken any new thoughts for Phil, but the reader can see the metaphor of darkness and obscurity as a monstrous weight on Phil who constantly relates it back to his reality with Mme. Dalleray's space at her beach home: It is linked to the relationship which ultimately winds up back to Vinca. Also, these metaphorical dreams continue to change the reader's perception of Vinca's and Phil's spatial boundaries. "Philippe chercha, entre les ombres, le regard de Vinca, pour éprouver la force de ce fil invisible qui les liait l'un à l'autre depuis tant d'années et les préservait..." (Le Blé, 116). The hidden or invisible link between Vinca and Phil appears to have been built over many years, maybe exceeding their present life and extending into the past for so many years, "tant d'années". This link seems to block them from moving further, as emphasized by the expresssion of protecting, suggested in "les preservait". Phil still envisions Vinca as the perfect mate in his mind.

C'est peut-être l'an prochain qu'elle tombera à ses pieds et qu'elle lui dira des paroles de femme: <<Phil! ne soit pas méchant... Je t'aime, Phil, fais-moi ce que tu voudras... Parle-moi, Phil...>> Mais cette année elle garde encore la dignité revêche des enfants, elle résiste, et Phil n'aime pas cette résistance. (Le Blé, 33)

Phil's sexual desire supersedes Vinca's maturity and makes him yearn for physical affection from her. His final dream incorporates his friend Vinca and his older lover, Mme. Dalleray, into one mother figure.

Mais ni Camille Dalleray, ni Vinca, dans son rêve, ne voulait se souvenir que Philippe n'était qu'un petit 
garçon tendre, pressé seulement de poser sa tête sur une épaule, un petit garçon de dix ans.... (Le Blé, 176)

Phil clearly has a Freudian Oedipus complex. He reaches out for his friendship with Vinca and a physical relationship with a woman as old as his mother, Mme. Dalleray. It also appears that he wishes to return to the comfort of his early childhood where his mother fulfilled these nurturing roles from the descriptions of his dream. He searches out a sanctuary of protection enlightened by his dream of female, mother-like images.

Où ses peines de petit garçon, ses fièvres de croissance, avaient trouvé la nuit protectrice, l'abri du drap mieux bordé, du papier fleuri contre lequel déferlait les songes, apporté par la pleine lune, les grandes marées ou les orages de juillet.... (Le Blé, 175 my emphasis)

The feminine imagery of the water, the light of the moon, the protection and the flower resemble life's nourishments. Moreover, Phil's discontent with both lovers leads to Colette's recuring use of the Oedipus complex in her male characters. In summary, Phil's dreams may not produce for him a new sense of self-awareness. On the other hand, both he and Vinca encounter spatial conflicts from the subconscious thoughts brought out because of these dreams.

The mixture of reality and dream world also extends to Colette's metaphorical commentaries where Vinca is directly related to a periwinkle. "Vinca...ça signifie pervenche" (Le Blé, 54). She is further related to other sea-like creatures such as the crab and the shrimp. 
D'un signe de tête hautain, la pervenche, Vinca aux yeux couleur de pluie printanière, répondit qu'elle allait, en effet, à la pêche... On savait que sa jupe à carreaux bleus et verts, qui datait de trois ans et laissant voir ses genoux, appartenait à la crevette et aux crabes. Et ses deux havenets sur l'épaule, et ce béret de laine hérissé et bleuâtre comme un chardon des dunes, constituaient-ils une panoplie de pêche.... (Le Blé, 31)

Her hat looks like the periwinkle and the thistle. Moreover, Phil's vision of Vinca as a shellfish indicates Vinca's close relationship with the water and sand. "...The crab was particularly associated with water and the moon, both typically representative of the great goddess who was supposed to bring all things to their doom" (Walker, 183). In Phil's mind he has associated Vinca with "la pervenche" who is leading him down the cliff to the sand, to her territory which is ultimately where Vinca sacrifices herself to Phil in order to keep him. Late one night Vinca and Phil walk down to their secret space, more so Vinca's than Phil's, since she knows it so well even in the dark. "Loin d'appréhender l'ombre, Vinca s'y guidait comme dans un pays ami et connu, l'expliquait à Philippe, lui faisait les honneurs de minuit et le promenait ainsi qu'un hôte aveugle" (Le Blé, 181). Finally Vinca, leading Phil to his "doom", gives in to him, which creates a mixed feeling of grief and pleasure for them.

Alors, je lui dirais: $<$ Ce n'est pas vrai. II ne s'est rien passé! Tu es ma Vinca de toujours. Tu ne m'a pas donné ce plaisir, qui ne fut pas un très grand plaisir. (Le Blé, 185)

This pleasure also carries some sadness in it. Since they decide to make love, they can never return to their previous way of relating. 
The friendship begins to fade.

...ll revint à elle, avec un élan qu'elle imita et qui mêla leurs genoux. II trouva alors la force de la nommer $<<$ Vinca Chérie > avec un accent humble qui la suppliait en même temps de favoriser et d'oublier ce qu'il essayait d'obtenir d'elle. (Le Blé, 183)

The day after the act of love, Phil plans out his defense and consolation to Vinca, pretending it was just a dream or something from the realm of the non-real. "C'est un rêve prématuré, un délire, un supplice pendant lequel tu mordais ta main..." (Le Blé, 186). This act of pleasure marks the final turning point of their relationship and a time to set new boundaries between them.

Another aspect of the dream world that affects Vinca's and Phil's space is the "white dove" which appears in Le Blé en Herbe and La Chatte. "...elle (Vinca) notait le passage, entre la plage et la maison, de Lisette pareille à un pigeon blanc dans sa robe voletante" (Le Blé, 166). Lisette, the younger sister, portrays the 'messenger' to the family just as a dove would be by carrying messages. As soon as Vinca sees Lisette she becomes concerned with the time and realizes others are looking for them. "Nous ne devons pas rester ici plus d'un quart d'heure, ou on nous cherchera..." (Le Blé, 166). Also, Vinca views this dove during a moment of self-transformation.

Aphrodite as a bringer of death, or "peace" sometimes bore the name of Irene, Dove of Peace. Another of her death-goddess names was Epitymbria, "she of the Tombs." Romans called her Venus columba, Venus-TheDove...the soul returning to the goddess after death was again envisioned as a dove. From this image, Christians copied their belief that the souls of saints became white 
doves that flew out of their mouths at the moment of death. (Walker, 253)

Walker's interpretation of the white dove as the symbol of peace directly correlates with Vinca's reaction proceeding her glimpse of Lisette, the white dove. "...puis elle (Vinca) réintégrait, âme et corps, l'amour, la jalousie, la fureux lente à se calmer..." (Le Blé, 166). Vinca calms herself after sighting the dove of peace: This dove is also the dove of death. In Vinca's condition a death is occuring, the death of her previous relationship with Phil. This particular scene of the text marks the beginning of their breakdown in trust through the outward admittance of their sexual bonds. Even though Vinca stands at the threshold of change, she chooses the pathway to security. "Ce que je vais faire? m'apprêter pour dîner. Et toi aussi" (Le Blé, 167). Presently, Vinca does not react by facing the inevitable. She decides to go on living as if nothing has happened.

It is evident in Le Blé en Herbe that Vinca possesses the powerful, female gaze or 'evil eye', at least from the male characters' point of view. Down on the beach, Phil daydreams of his virility.

...son rêve viril où l'amour, devançant l'âge de l'amour, se laissait lui-même distancer par ses fins généreuses et simples, fonça vers des solitudes dont il fut le maître. (Le Blé, 71)

He is full of pride because Vinca had just stared at him in an angry way, but did not pierce his soul. "It seems men were very much 
adverse to meeting a direct glance from a woman" (Walker, 295). This glance bears no lasting effect on Phil. "Elle ne daigna pas répondre et le regarda en riant silencieusement...dont Philippe se sentit comme blessé. Mais elle se détourna, et il la vit sans trouble" (Le Blé, 69). He remains powerful until Vinca confronts him about his affair. Here, Vinca triumphs and her 'regard' prevails. "Women were credited with the ancient goddess's power to overlookto curse someone with a glance" (Walker, 294). She takes Phil's power away and gains control of her space through her eyes. "...mais le vindicatif regard de Vinca lui déconseilla la plaisanterie" (Le Blé, 161). Ultimately Vinca, as a girl, is not as experienced as Colette's other characters about controlling her own space, however she does grow in awareness during her periods of trial and error.

Moving back and forth from the state of the dream world to reality also applies in La Chatte. Alain dreams of a dark paralyzing force which envelops him.

Mais il se sentit paralysé par le regard chaud et dangereux d'un figurant brun, au profil grec, perforé d'un grand oeil de carpe..."la zone d'ombre...La zone de l'ombre..." Deux longs bras d'ombre, gracieux et tout clapotants de feuilles de peuplier accoururent au mot "ombre" et emportèrent Alain. (Le Blé, 25)

Again, the dream is not analyzed by the protagonist, but, the reader sees Alain's subconscious thoughts. Since Alain had previously associated Camille's gaze in the mirror with eyes that spy upon him, the dream is therefore a manifestation of his fears of Camille. 
The Eye whose appearance strikes terror was the original prototype of the evil eye which, like the petrifying. glance of Medusa, was usually associated with women and was feared by simple folk everywhere, up to the present day. (Walker, 294)

Alain sees Camille's look in the mirror and cannot rid himself of the anxiety which overtakes him afterwards.

Dans le miroir, en face d'eux il reçut le regard de Camille, noir de reproche, qui ne l'attendrit pas...Et retrouvant dans le miroir l'image vindictive, les beaux yeux noirs qui l'épiaient, il enveloppa Camille de ses deux bras. (La Chatte, 16)

In each case, in the mirror and in the dream, someone is overtaking another with smothering arms. The territorial boundaries collide. The real world merges with the dream world through Alain's fear and anxiety and this manifests the real problem of spatial conflict in the relationship. He appears to be suffocating because of Camille. The "reality/dream-world" opposition implies an internal spatial conflict: One in which the male character acts out his real conflict of feelings and his resentments of his "M/other's" act of castration or his loss of power. The woman lover embodies both other and mother in Colette's imagery.

The mother is the white dove in this story. She is not the informant, but knows everything about Alain, Saha and Camille.

Un pigeon blanc furtif bougea derrière les wégélias et les deutzias à grappes rosées. $<<C e$ n'est pas un pigeon, c'est la main gantée de maman.>> Le gros gant blanc, à ras de terre, relevait une tige, pinçait des brins d'herbe.... (La chatte, 31) 
The mother's cutting hand escorts the reader directly into Alain's metaphoric castration. The cat gives him a love bite that makes him bleed.

II voulut caresser le crâne large, habité d'une pensée féroce, et la chatte le mordit brusquement pour dépenser son courroux. II regarda sur sa paume deux petites perles de sang, avec l'émoi coléreux d'un homme que sa femelle a mordu en plein plaisir. (La Chatte, 31)

In the mother's garden, Alain can freely play with his cat while the mother, 'the white dove', can watch over him and keep him from leaving this safety zone. The bird in the garden is a danger to Camille in that it sees all, and has some control over life circumstances, just like Lisette in Le Blé en Herbe.

In La Vagabonde Colette uses many dream world illusions which specifically refer back to the main character and her spatial conflicts with others. Renée Neré constantly looks into the mirror and talks with or judges her other self.

The initial important image of the mirror where Renée faces herself and sees a heavily made-up "counselor" who actually talks to her and questions her decisions to lead an independent life; the dichotomy between the glitter and the bright rowdiness of the music-hall stage and the loneliness, fatigue, and introspection of the writer and blue stocking; past love, present lack-this series of reflections and oppositions sets the situation. (DLB 65, 49)

This is the self on the opposite side of reality which reflects back to her real world and depicts the real Renée. "...the reflection was considered part of the soul" (Walker, 660). Renée witnesses her true 
self on the other side of the mirror. The last name Neré is backward the same as Renée so when it is reflected in the mirror, just as when Renée herself is reflected in the mirror, she finds the same person and name only in a purer sense. In the mirror a reflection is broken down into fragments of its reflector and is inverted.

Therefore, it would be the purest slice of reality that can be seen of oneself, especially as far as introspection is concerned.

Le grand miroir de ma chambre ne me renvoie plus l'image maquillée d'une bohémienne pour music-hall, il ne reflète... que moi. Me voilà donc, telle que je suis! Je n'échapperai pas, ce soir, à la rencontre du long miroir.... (Vagabonde, 13)

Renée expresses her feelings, projecting them out through the opposite self as did both Alain and Phil, through their dreams.

...le cachet en ville... ces trois mots-là ont le don de me démoraliser. Je n'ose pas le dire à Brague, mais je l'avoue, en regardant dans la glace ma figure d'enterrement, avec un petit frisson de lâcheté qui me grippe la peau du dos.... (Vagabonde, 48)

When Renée thinks about confronting the past and dancing in front of people from this space her counselor from the other side of the mirror devaluates her, and her body. Subsequently, she judges her internal thoughts as well.

II est trop tard pour fuir, j'ai rencontré une fois de plus ma conseillère sans pitié, celle qui me parle de l'autre côté du miroir...Ta simplesse de petite fille n'a pas hésité à le reconnaître et ne lui a marchandé ni ton corps, ni ton coeur enfantin. (Vagabonde, 146) 
Colette intimates that Renée is like Alice de l'Autre Côté du Miroir, as she uses a literary technique called "intertextuality" to evoke the image of the non-real and real worlds from both her novel and Alice's tale. The mirror is a projection of the non-real onto the real which investigates, through other points of view, the problem at hand.

Colette does not refer specifically to the white dove in $\mathrm{La}$ Vagabonde, however she does recognize another type of bird throughout the text. 'The big canary' is what Renée calls Max which is similar to Vinca's role in Le Blé en Herbe, who is portrayed as a periwinkle. "Mais Hamond n'est pas seul: il cause sur le trottoir avec... avec Dufferein-Chautel cadet, prénommé Maxime, et dit le Grand-Serin..." (Vagabonde, 74). What she learns of Max is that his features truly seem like a big canary when he is standing, because he is so tall. "Le grand serin" is a slang derogatory term in French which means "the dumb one" and he is tall. However, it also calls forth the image of a bird, in its prime meaning.

Debout, c'est vraiment un grand serin, raide, emprunté, tout en os. Assis, ou demi-allongé sur le divan, il semble s'assouplir tout à coup et goûter la grâce d'être un autre homme.... (Vagabonde,87)

The lover, imagined as a bird, is once again the message bearer and the holder of information even with a negative implication. Max finds Renée sleeping upright in her chair and ridicules her physical appearance accusing her of hiding something from him. He knows that she is keeping a secret, and shows his jealousy. 
Quand vous dormez, vous n'avez pas l'air de dormir! vous avez l'air... eh! enfin, vous avez l'air d'avoir fermé les yeux pour cacher une joie plus forte que vous! Parfaitement! vous n'avez pas un visage de femme endormie... Enfin, vous comprenez ce que je veux dire, bon Dieu! C'est révoltant! Quand je pense que vous avez dû dormir de cette manière-là devant un tas de gens, je ne sais pas ce que je vous ferais! (La Vagabonde,117)

Renée is trying to leave his space and he senses her desire to escape. At last, she perceives the extent of Max's comprehension of their situation. "Je le regarde, plus méfiante que je ne le fus jamais, déconcertée de trouver en cet homme, dès qu'il s'agit d'amour entre nous, une intelligence, une aisance spéciales..." (Vagabonde, 119). Although Colette uses a different metaphor for the bird in $L a$ Vagabonde, the ideas behind it were similar in all three novels. Birds, whether a canary or a dove, always have a message to give from their songs. As well, they can survey any predicament with insight and understanding.

Finally, the 'regard' or 'the evil eye' is approached in the same manner in all of the author's texts. Renée, as Camille and Vinca, uses the stare to make her territory known and to remove unwanted persons from it.

Je ne dis rien à cet imbécile. Moite, essoufflée encore, la robe demi-ouverte, j'essuie mes mains en le regardant avec une férocité si visible que sa belle phrase meurt soudain, coupée.... (Vagabonde, 23)

Moreover, at Renée's level of adulthood she concludes that there is some power in a gaze. She can read a person's body language and instinctively interpret beyond the shell, into the soul. "Je ne sais 
pas ce que lui disent mon regard et mon silence, mais sa figure change tout à coup..." (vagabonde, 23). Renée's maturity has lead her to an understanding of the 'regard' and throughout most of the story she notes the use of its effectiveness, coming either from her or from others. "Heureux de mon regard qui l'a reconnu, il suit de la tête mes mouvements..." (Vagabonde, 63). The human "tropism" as mentioned by Nathalie Sarraute, is exhibited by the characters around Renée, opening her up to the truths behind their facade. She begins to decipher personal relationships at a new and deeper level. "Margot eut un de ces regards qui la font paraître très grande, qui ont l'air de tomber de si haut!" (Vagabonde, 67). Renée watches her friend's facial expressions as Margot hears about Renée's relationship with Max. By this, she realizes that her friend is sad.

Once more, Renée makes apparent her feelings through the look that she gives Max. "...j'appuie sur mon amoureux un regard désarmé qu'il ne m'a jamais vu" (Vagabonde, 113). He does the same, and insightfully she starts to understand what Max feels towards her. "Je sentais le regard de mon amoureux se poser, assuré, sur toute ma personne..." (Vagabonde, 130). Max has a real physical desire for Renée and displays it from one simple look. Where Renée is perhaps better than the other of Colette's characters is in her comprehension of the effectiveness of body language and its role in spatial boundaries. She accepts and translates her encounters with others because, in some small way, she gains personal strength by understanding different looks her friends give her. As well, Renée 
uses the 'evil eye' or 'regard' to give a message as to what her boundaries are for those around her.

In conclusion, spatial boundaries in Colette's work are represented by tangible, non-real, mental or physical spaces through the" in/out" or "dream world/reality" oppositions. These binary oppositions define the relationships between the characters. They show the different levels of interaction that each protagonist faces in terms of relating with another person. Unfortunately, the majority of the time, Colette carries and portrays a pessimistic view of male and female relationships. The characters struggle when placed together, mostly because their spaces do not fit together as nicely as two pieces of a puzzle. Therefore, another level in the development of relationships is that of personal evolution. In order to understand others and their space, one must start by looking at the self. 


\section{CHAPTER ॥}

\section{FEMININE CONSCIOUSNESS}

Feminine consciousness develops out of an individual's capacity to identify with the justifiable philosophies and potential empowerment which lie outside of the realm of patriarchy: However, this awareness can also spring out of a personal need for freedom and liberty, not just for the female self but for all females and males.

What follows a woman's discovery of personal authority and truth is, of course, a blend of her own unique life circumstances and attributes. But as we listened to many stories, we began to hear how a newly acquired subjectivism led the woman into a new world, which she insisted on shaping and directing on her own. As a result her relationships and self-concept began to change. (Belenky, 76)

This happens in all three works by Colette: Vinca from Le Blé en Herbe, Camille in La Chatte, and Renée in La Vagabonde all develop a sense of their female identity. When Colette writes, she creates a need within her stories for liberation of the female. "...it (Colette's works) tells a story of a soul's quest for liberation--not political liberation, but spiritual liberation..." (Twentieth Cent. Lit. Crit., 194). Colette's stories are set within the patriarchal world, one from which the female character must escape. This chapter will treat the female protagonist's process of liberation, silence, the 
female voice, and male patriarchy in each of the three novels by Colette.

In Le Blé en Herbe, Vinca's desire--to mature and to comprehend her relationship with Phil--teaches her to understand herself in order to communicate verbally and non-verbally (physically) with others. "Il percevait joyeusement leur âge, leur amitié déjà troublée, son propre despotisme et la dévotion hargneuse de Vinca" (Le Blé, 55). In the beginning, Phil represents the traditional male figure and Vinca, while seemingly docile yet more sophisticated than Phil mentally, tends to eventually break away from her role as an oppressed female lacking physical refinement. At first most of her changes are physical. This is when Phil realizes that she is not a fragile female but discovers her robustness and her maturing face which is: "Le visage de Vinca, ce visage de femme qu'elle ne montrait qu'à lui, et qu'elle cachait à tous derrière ses quinze ans de jeune fille raisonnable et gaie..." (Le Blé, 59). Vinca is growing out of her youth and moving into young womanhood. Phil notes these developments and classifies them as masculine. "Comme elle est solide...Je croyais qu'elle était douce..." (Le Blé, 110). Even though he notices her external transformations, what Phil refuses to recognize is Vinca's internal changes. "Elle tendit l'oreille, sans le regarder, et tout son corps exprima, dans ce mouvement léger, l'ironie et l'indépendance" (Le Blé, 156). Vinca is realizing that she needs her freedom and that through the development of her body she herself is transforming. "Elle ferma les yeux, renversa la tête, caressa de la voix ses dernières paroles, 
et ressembla, avec une fidélité étrange, à toutes les femmes..." (Le Blé, 157) Phil does not understand this transformation even though he can see it unfolding before him. "Vinca rit, d'un rire saccadé et déplaisant, comme n'importe quelle femme blessée" (Le Blé, 158) Phil reacts to her actions by confessing his own pain and suffering. His narcissism helps to complete Vinca's transformation: She no longer needs Phil's power, instead she is testing and discovering her own.

Le Blé en Herbe underscores Vinca's power through her dialogue. "Tais-toi, Vinca...Non! je ne me tairai pas! D'abord nous sornmes tout seuls, et puis je veux crier!" (Le Blé, 159). She uses her mouth to express anger and release her emotions. What women cannot do with action, they tend to do with words. This female voice or form of expression is liberating in so far as females tend to be verbally oppressed in the male dominated world. "...attributes traditionally associated with the masculine are valued, studied, and articulated, while those associated with the feminine tend to be ignored" (Belenky, 6). Vinca refuses to be ignored as she pours out her thoughts. She feels that Phil is trying to satisfy his guiltridden feelings by explaining his affair to her.

Tu m'as amenée ici parce que tu voulais raconter, repasser tout ce que tu as fait avec elle, pour le plaisir de t'entendre, d'entendre des mots... de parler d'elle, de dire son nom, hein, son nom, peut-être.... (Le Blé, 159)

Subsequently, Vinca releases her emotions and frees herself from the patriarchal bond, represented by Phil. Phil tries to recapture her innocence and ignorance by directly suggesting that she is still too 
young to understand life. "Vinca chérie, tu vois les bêtises que tu dis! Des bêtises de jeune fille ignorante..." (Le Blé, 170). Phil does not recognize Vinca's truth, her internal knowledge that comes from experiences of hurt and the strength manifested thereafter.

Female strength may not only come from experiences but also from intuition or a sixth sense which aids in the creation of stability during life's struggles. "...Puis elle réintégrait, âme et corps, l'amour, la jalousie, la fureur lente à se calmer..." (Le Blé, 166). As Belenky points out, women use their intuition to regroup their thoughts and emotions in order to focus themselves.

As a woman becomes more aware of the existence of inner resources for knowing and valuing, as she begins to listen to the "still small voice" within her, she finds an inner source of strength. (Belenky, 54)

Vinca's feminine consciousness begins to bud as does her "still small voice". Her intuition expands during the late stages of the book when she makes a reference to women's growth in knowledge. "Remercie-le d'autre chose Phil. Est-ce que tu ne crois pas que j'en sais autant que la première femme qu'il a créée?" (Le Blé, 170). Her cynicism relates to what women have endured and learned since the first female was brought into the "male" world. Finally, Phil does realize Vinca's womanhood or coming of age, at the very end, when Vinca refers to having noticed "les deux fléaux" cutting the wheat as they were making love. The symbolism of the flailing of the wheat and Vinca's loss of virginity relates back to the name of the novel, "The Tender Shoot", which in either case is "cut" and lost forever. "Involontairement il compara à cette vigilance de tous les 
sens féminins, le souvenir d'une autre habileté féminine..." (Le Blé, 181). Vinca senses strengthen her character as a female, considering she is able to open herself up to the noises around her during such a valuable moment in her youth. Vinca may be young but she discovers much about how to be a woman even before she enters that stage of young maturity.

In La Chatte, the female protagonist, Camille, not only attempts to cross spatial barriers and win love, she also succeeds in gaining a new perspective on her own femininity. Her mind expands and she comes to new realizations about youthful life and living. The robustness and abruptness of her childlike ideas change as she shifts and grows into her new state of awareness.

Colette's fiction represents a female experience of the patriarchal social order of early twentieth-century France, and read from this perspective reveals a substantial degree of social, and ultimately of economic, realism. (Holmes, 61)

Through her actions, more than her words, Camille reveals her womanhood and the challenges she faces confronted by the patriarchy. "Colette is the embodiment of the emancipated woman, whose social status and economy and sex life are unhectored by male hegemony..." (Phelps, 115). Just as Colette, her character Camille grows out of the male world and comes into her own feminine awareness.

"The transition from girlhood to womanhood is invariably represented in Colette's texts as a fall or a decline" (Holmes, 61). 
The fall or decline does not appear much different for the male character, Alain, than it does for Camille. Alain's obvious Oedipus complex leaves him bound to the matriarchy, represented by his birthplace and youth. Camille may leave the patriarchy behind at the end of the book, but she has made many compromises on her journey toward freedom. In the beginning, she is naive and lacking the mature woman's perspective. Broadly, she wants to be loved by Alain so much, that she cannot see the compromise she makes for that love. Camille is a modern, moving heroine, but desires to settle down with a stale aristocrat who represents the patriarchal economic and social system in France. Alain's incisive use of degradation towards Camille is what she fails to recognize at the beginning of the story. "Mais il ne la repris que sur sa manière de dire 'on' à la place de 'nous' et elle crut à un reproche tendre" (La Chatte, 13). Quite often, he reproaches her in the same manner. In taking note of her beauty, he indirectly compliments her. This truly ends in mockery since he likes her shadow better.

Qu'elle est belle sur le mur! Juste assez étirée, juste comme je l'aimerais... c'est dommage... II se reprocha mollement ensuite son inclination à aimer.... (La Chatte, 14)

After having completely mistreated her, the future bride, perhaps full of illusions, does not realize Alain's deep malicious intent. She nonchalantly continues to try and gain his love through her attempts at mixing spatial boundaries. 'Qu'est-ce que tu as, ce soir? Viens m'aider à mettre ma cape, au moins..." (La Chatte, 14). Camille has 
not yet accepted her fate which is, inevitably, he will not love her and will not change to accept being with her.

As the progression of the story unfolds, Alain's personality comes in clearer focus. His power struggle weakens at the "Quartde-Brie". Camille can't transform Alain and help him overcome his Oedipus complex. There are three stages to this Oedipus complex as seen by Freud. The first stage, between ages one and three, the baby attaches himself to the mother figure for nurturing and security. At the second stage, ages three to twelve, the child attaches to the father figure and leaves the mother figure behind. The third stage, when the transformation from adolescence/youth to adult occurs, the child leaves the nest of the family, rejecting both the mother and the father, finding a spouse which represents the replacement. Alain never reaches the third stage and, searching for a female replacement of his mother, while not truly wanting one, he reverts back to his mother figure. "There will be hope for Alain if he can be reborn at some future time and finally free himself from the womb of the garden" (Forde,366). As Forde suggests here, Alain definitely has a final rite of passage to take before he can be free. The critic also alludes to a much larger picture within the story to which it is agreed upon here. "...the initially less flattering view of Camille, and the tendency to identify Alain with Colette through the garden conceal Camille's quality at first" (Forde, 336). To be added, Camille might be an oppressed young female but, out of love, she chooses to continue that oppression by marrying Alain who represses her even further, until they move to the "Quart-de-Brie". 
The 'coming of age' occurs one evening when Camille and Alain dine out. Camille hints at pregnancy and Alain, still child-like, reacts to her subtleness. "Et ça t'a (Alain) bouleversé à ce pointlà?.....De joie ou.....d'embêtement?" (La Chatte, 98). Although Alain is nervous, Camille remains calm and strong, a step closer to her freedom.

Sereine, équilibrée dans l'optimisme par le vin traître, elle fumait et parlait comme si elle eût été seule, le flanc à la table et les jambes croisées. (La Chatte, 97)

Looking closely at 'eût été seule', there is a suggestion that Camille really is alone inside, and that she will soon be without Alain. "Camille avançait tranquillement dans sa vie de femme, parmi les décombres du passé d'Alain" (La Chatte,99). Camille's quest for personal power comes shortly after this point when she and Alain fight about Saha. At first, the reader is given a warning of what is to come. Saha is waiting on the balcony for Alain when they return from dinner. "-Regarde comme elle t'attend! -Tu as de bons yeux, dit Camille baillant" (La Chatte, 102). Alain becomes tense and makes a nervous remark. "- si elle tombait! Ne l'appelle pas, surtout! - Tu peux être tranquille, dit Camille si je l'appelais, elle ne viendrait pas." (La Chatte, 102) This may not have reassured Alain but it did fix the destiny of the story, by foreshadowing. Soon thereafter, in the house while arguing, Camille discovers a way to her freedom: Something clicks in her mind. "Une sorte de gaieté amère passa dans les yeux de Camille, mais elle ne parla pas" (La Chatte, 104). Silently, the reader detects a sense of revenge coming 
from this young woman. Her power begins to reveal itself. That same night she and Alain don't sleep together, she spends the night alone and awake, analyzing the male mentality.

Mais elle ne pouvait pas comprendre que l'amour sensuel de l'homme est une saison brève, dont le retour incertain n'est jamais un recommencement. (La Chatte,107)

This helps to demonstrate Camille's change from adolescence to young adulthood. She wants to understand Alain's behavior, so she no longer ignores it and hopes that it will disappear, or that she can change it. Finally, she begins to fight against it.

Camille fights against Alain's behavior by wishing to push the cat out of her space. This may have been an attempt at letting Alain go, which is in response to Alain pushing Camille out first, subconsciously. In unveiling her own power, she pushes Alain and what he represents away: She finally discovers that he will never love her, nor any other woman as much as he does his cat Saha.

In Alain's case, this (womb-like) existence is symbolized by the maternal house and garden with its presiding genius la chatte, in whom all his tenderness and dreams of idealized love have crystalized. (DLB65, 60)

This cat that represents the garden, the mother's house, his bedroom and bedfellow, is in essence all bound to Alain's complex. He is so attached to his mother that he cannot find a replacement for her. "Même une femme, continua Camille en s'échauffant, même une femme tu ne l'aimerais pas sans doute autant" (La Chatte, 130). Alain probably never could love another woman as much as he does the cat because the cat represents the other as the ideal lover. 
Alain attaches himself to his traditional background because it reminds him of security, of the mother. "Alain does not leave his young wife who is not at all feminine- because he loves his cat Saha more, but because with Saha he can be himself" (Crossland, 209). Here, Crossland has a traditional view. He identifies with Saha the cat because the cat is his friend that comes with him from his origin of security and his true association with the female world. Also, Alain does not have to give beyond food and affection to a cat. With a woman the difficulty of interaction is more subtle and more demanding. The cat is woman-like in her mannerisms, however. The revealing of Saha in a way that ties women to animals and animals to nature leads the reader to yet another aspect of Camille's growth in feminine consciousness.

The role women play in nature in La Chatte is not related to the traditional feminine stereotype. "...female space, as distinguished from 'patriarchal space', is represented by the garden. The new female space is necessarily different..." (Ladimer, 163) The hardest part of La Chatte is its ambiguity; the garden is the male retreat where Alain regresses into a child-like figure playing freely with the cat. It is also a point of return and rest at the end of the book. The libertine character has little attachment to this sanctuary. After all, it is Alain's mother's garden and she indirectly hinders Alain from moving out of his comfort zone. "But the readers admire Alain's cat, and they understand his longing for the restful tranquility of the garden..." (Ladimer, 163) The reader views the garden as a place of joy and rest and it is here where the garden 
becomes confusing since it is also a hindrance for the young man's rite of passage.

The reader's ambivalence, and the resulting ambiguity... is finally related to feelings about the garden space, nostalgia for the peace and tenderness of the garden are natural and inevitable. (Ladimer, 163)

Again, the mother comes into full view as an obstacle even though she is a nurturer. "It is the tension between the allegiance to and difference from the mother that ultimately creates ambiguity." (Ladimer, 163).

At first, the garden evokes a feeling of feminine fertility. "La grasse odeur des terres à fleurs, nourries, provoquées sans cesse à la fertilité." (La Chatte, 11) Later, there is some sort of darkness that seems to surround this garden. "Le chèvrefeuille, qui drapait un arbre mort..." (La Chatte, 8) Represented early in the text, this metaphor elicits life and death in an intertwining way; the dark side would be the dead tree. This obscurity is what Camille discovers during the destruction of her relationship. Alain's mother is metaphorically seen in the garden as well. It is at this juncture that the -reader realizes that the garden is ultimately cultivated by the almost always silent mother.

Un pigeon blanc furtif bougea derrrère les wégélias et les deutzias à grappes rosées. "Ce n'est pas un pigeon, c'est la main gantée de maman." Le gros gant blanc...relevait une tige, pinçait.... (La Chatte, 31)

The repetitive mother figure is now disguised wearing a glove, cutting. It seems to be the subconscious crime of the entire story, 
the mother's silent control of her son. As Camille discovers this tragedy through Alain's rejection of her, the "Quart-de-Brie" and her overall space, she decides to drive away and ultimately move on.

A final resting place unfolds for Colette's third character who has already traversed the years of struggle and heartache. Renée, in La Vagabonde, appears as a mature woman who has confronted her issues of womanhood, yet in essence as all of Colette's main female characters, she grows from loneliness through oppression into liberty.

Colette remains, even now, the century's best translator of feminine vigor into words, the woman who brought to her vocation of writing the most generous measure of experience and health. La Vagabonde still reads as a remarkably just and debonair study of a female consciousness waking to the possibilities of independence.... (20th Cent. Lit. Crit. vol. 16, 117)

Colette's protagonist achieves freedom after she leaves her first husband, but not for a great length of time. Renée works in a musichall and even this environment is restraining to her. Moreover, she encounters another man, Max, who desires to control her and imprison her.

On dit aussi de moi que $\ll$ je fais du théâtre $\gg$, mais on ne m'appelle jamais actrice. Pourquoi? Nuance subtile, refus poli, de la part du public et de mes amis euxmêmes, de me donner un grade dans cette carrière que j'ai pourtant choisie... Une femme de lettres qui a mal tourné: Voilà ce que je dois, pour tous.... (La Vagabonde, 15) 
Renée does not feel worthy of status since she deems herself a labeled woman. She has a history as a divorcée and as a "danseuse". She possesses low self-esteem and only through time does she realize the importance of self-empowerment. By staying with her husband she subconsciously keeps herself under his rule: He treats her very badly. "Pour lui, l'adultère n'était qu'une des formes - et non la plus délectable - du mensonge (Vagabonde, 29)." There are extra-marital affairs, as well as domestic violence which occur. At this, it appears indisputable that Renée had to get out of the relationship. However, this is not the case inside of the story: Colette invents a typical patriarchal world in which Renée must cope.

Personne ne comprit rien à notre séparation. Mais eût-on compris quelque chose, avant, à ma patience, à ma longue, lâche et complète complaisance? Hélas! il n'y a pas que le premier pardon qui coûte... Adolphe connut vite que j'appartenais à la meilleure, à la vraie race des femelles : Celle qui avait la première fois pardonné devint, par une progression habilement menée, celle qui subit, puis qui accepte... Ah! le savant maître que j'avais en lui! Comme il dosait l'indulgence et l'exigence!... II lui arriva, quand je me montrais trop rétive, de me battre. (Vagabonde, 32)

As Renée relates Adolphe to her past, she is able to recognize and pinpoint the mistakes they made together: Nevertheless, she does not release her presently harbored feelings towards all men. "Il y a encore bien d'autres Taillandy, que je ne connaîtrai jamais, sans parler de l'un des plus terribles..." (Vagabonde, 29). She is not able to trust other men since her divorce and through silence has 
discovered a way to keep them at bay. Colette uses the female silence throughout her works, but in La Vagabonde, it becomes vital to her female protagonist.

Depuis trois ans, voilà de quelle sorte sont mes conquêtes amoureuses... le gigolo des secondes galeries... Le silence les décourage bientôt.... (Vagabonde, 25)

Renée eventually learns through the progression of her own story, that silence equals obedience, and she carefully applies this knowledge until the final moment when she must speak.

The (silent) women see blind obedience to authorities as being of utmost importance for keeping out of trouble and insuring their own survival, because trying to know "why" is not thought to be either particularly possible or important. (Belenky, 28)

Communication remains a large part of Colette's human interaction, yet at times, her women characters have sacrificed this connection knowing the importance of reticence. Renée chooses when to be still and when to speak with Max because she acknowledges the danger of her own tongue.

Je ne sais pas vous parler, pauvre Dufferein-Chautel. J'hésite entre mon langage à moi, un peu brusque, qui ne daigne pas toujours finir les phrases, mais chérit la précision d'un terme technique... A force d'hésiter, je choisis le silence.... (Vagabonde, 93)

When Renée discovers an escape from her life in Paris, she then speaks up. This is the beginning of her liberation and her awakening. "Bonjour! Vous savez, je pars!... Sans m'arrêter à ce que l'intonation de mon amoureux prend, malgré lui, de bref et d'inquisiteur, je roule 
mes gants, je retire mon chapeau" (Vagabonde, 113). She grows into a higher level of consciousness and womanhood, seemingly to the equivalent of Colette's wise woman, as will be termed the "crone".

The "crone", in Colette's terms, the sage, is the aged woman who understands life well. She knows when to sacrifice and hold her tongue. She also knows when to speak.

The Crone is of value, too, as an indication of the power of women's nay-saying, hence of their best hope of exerting control in a male-dominated world where they are expected always to say yes. The Crone's title was related to the word crown, and she represented the power of the ancient tribal matriarch who made the moral and legal decisions for her subjects and descendants. (The Crone, 14)

With her decision to leave, Renée suddenly matures beyond her own life's experiences, she undergoes a transformation in spirit.

II faudra donc, pendant quarante jours, soutenir cette lutte contre la fatigue... il faudra trouver et renouveler sans cesse en moi ce trésor d'énergie que réclame la vie des errants et des solitaires? II faudra lutter, enfin, -ah! je ne saurais l'oublier! -- contre la solitude ellemême... Et pour arriver à quoi? à quoi?... (Vagabonde, 136)

Renée becomes the vagabond who plunges deeper into herself to find the strength and wisdom to fight against the life's weariness. This journey that she wishes to undertake is her salvation and her rite of passage into becoming the "crone".

Colette divides La Vagabonde into three parts which corrolate with three stages of Renée's personal evolution. The third part is her shift into the crone. It commences with her departure on the 
train. "Je suis seule dans le wagon... Après un court abattement qui suivit l'agitation du départ, j'étais tombée dans une immobilité maussade qui me faisait espérer le sommeil" (Vagabonde, 195). Alone, staying in the compartment inside of the train, Renée discovers her own deep springs of solitude. It is as if Colette writes, using a "mise en abyme"; the "train" is Renée's body and the "wagon" her mind. Renée herself experiences her mental fatigue and age inside of these physical bounds. Immediately following, she blends with nature, tuning in with it just as the old woman crone does.

Le troglodyte, enchanté, un peu gris, chante aux étoiles, et moi je rêve, j'écoute le vent noir qui se lève et remonte le quai du Rhône avec un renflement marin. D'où vient que je me balance ce soir sur une houle invisible comme un navire que renfloue la mer.... (Vagabonde, 207)

The evocation of the Rhône water is going to give her strength at the end of her journey, at a point when she has travelled deep enough into the countryside where she is safe and cannot be touched by Max's power. "Having entered this world, Renée can open herself completely to the powers of nature" (Cothran, 33). Renée writes her final letter to Max saying good-bye and finishes her journal. "Les lettres qu'elle écrit à Max sont romantiques mais désincarnées. Enfin, elle reprend perspective et ne peut renoncer à sa liberté" (Fisher, 214). Her liberty is the exact word, her freedom from the patriarchy and bondage of marriage with Max.

Adieu, mon chéri, je m'en vais, pas bien loin d'ici, dans un village; ensuite, je partirai sans doute pour l'Amérique, 
avec Brague. Je ne vous verrai plus mon chéri.

(Vagabonde, 245)

Renée explains to Max her sadness of aging and becoming the crone.

She identifies her birth-giving right as something that she is losing and does not want this to ruin his fatherhood. She also feels the pull between the good and the bad of aging.

Le meilleur de moi, ce serait, dans quelques années, cette maternité ratée qu'une femme sans enfant reporte sur son mari. Vous ne l'acceptez pas, ni moi non plus.

C'est dommage... II y a des jours, -- moi qui me regarde vieillir avec une terreur résignée, -- des jours où la vieillesse m'apparaît comme une récompense.... (Vagabonde, 245)

By the end of the novel, Renée detects within herself, a mental and physical femininity as she relates to others as a whole being, free from the captivity of male domination. She makes her own decisions and takes her liberty at the end, realizing her female self.

Feminine consciousness in Colette's works gives rise to many different concepts such as the female plight in the male dominated world, an increasing sense of the female protagonist's self worth, her closeness to nature, and her relationships with others and to herself. This study, spread out over three of Colette's novels -- Le Blé en Herbe, La Chatte and La Vagabonde -- reveals a progressive movement or cronology in the three female characters' growth. They transform from Vinca's adolescence, through Camille's adulthood, and into Renée's maturity of the wise woman. Each has to go through a process of overcoming a domineering male, learning a woman's sacrifice of silence or her power of speech. They all come to 
understand more about the nature around them, and finally they learn to take back power and use it to gain a sense of liberty. Vinca's liberty is an internal peace, while Camille's is an external liberation of leaving. Renée chooses both peace and the freedom to leave. In all, Colette brings to life the idea of female sovereignty in a time when women were bound by the social conditions. In the early twentieth century women were still finding their place and reacting against the atmosphere of the time. 


\section{CHAPTER III}

\section{GENDER}

The subject of gender in Colette's works is exposed on several different levels. Colette confronts sexual ambiguities in her narratives through physical descriptions. Her protagonists make reference to one another's physical appearance, describing each other as either effeminate and weak or masculine and virile. Secondly, she reverses the stereotypical "active/passive" roles played out by the characters, hence reversing the masculine which is traditionally active, and the feminine which is traditionally passive. Androgyny is also explored as another alternative to role reversal. Last, she associates the role of female sexuality and rage to the feline disposition. In each case, gender is examined as a major element in Colette's work. Consequently, it becomes a major topic of discussion in female writings from the early twentieth century, and defined by contemporaries like M. H. Abrams in his book on literary criticism.

It is widely held that while one's sex is determined by anatomy, the concepts of "gender" --often traits that constitute masculinity and femininity --are largely, if not entirely, cultural constructs, effected by the omnipresent patriarchal biases of our civilization. (Abrams, 208) 
By sensitizing the reader to the gender issue, Colette gains further recognition by later feminist critics. Certain contemporaries have studied Colette, as well as other early modern French women writers, and they comment on the problematics of gender in their writings. "As Anne Rosalind Jones has observed, sexual identity is always constructed from experiences in the family and reinforced by the ideologies of culture" (King, 17). Colette is quick to point out that patriarchy is the basis of Western culture. Her novels, Le Blé en Herbe, La Chatte and La Vagabonde all mirror the constructs of her society.

Bethany Ladimer, in a review of several of Colette's works, states that Colette's protagonist, in Le Blé en Herbe, appears the most ambiguous in terms of her sexuality.

By virtue of her extreme youth, Vinca is by far the most androgynous of Colette's women... The two parts of this description, one strong, athletic, and suggestive of virility, the other insistent upon the feminine beauty of her blue eyes, recur throughout the novel. (Ladimer, 156)

Phil, by the same token, is effeminate and yet wishes to be assertive in order to affirm his masculinity. His physical appearance is described as that of a young girl: Mme. Dalleray, Vinca, Colette and Phil himself all associate his body with womanlike features.

II (Phil) vit, dans un visage que la lassitude amincissait, des yeux languissants, agrandis par leur cerne, des lèvres qui, d'avoir touché une bouche rougie, demeuraient un peu fardées, des cheveux noirs en désordre sur le front, -des traits plaintifs, et moins pareils à ceux d'un homme qu'à ceux d'une jeune fille meurtrie. (Le Blé, 107) 
Phil wrestles with his internal emotions so as not to show them for fear of seeming weak. "A man-machine conducts his life in a defensively cerebral way. Emotions are seen as weaknesses, and are therefore repressed" (Goldberg, 30). This so called 'fragility', that he desires to hide, comes out. Consequently, his masculine side battles his feminine side.

II cachait, de son mieux, une douleur qu'il ne comprenait pas. Qu'avait-il donc conquis, la nuit dernière, dans l'ombre parfumée, entre des bras jaloux de le faire homme et victorieux?...de souffrir?...de défaillir de faiblesse devant une enfant innocente et dure?...de trembler inexplicablement, devant la vie délicate des bêtes.... (Le Blé, 113)

Even Vinca reinforces the gender stereotype at this juncture. She does not know how to react towards Phil, believing that he should not show a 'weak' emotion by crying. She, as the unsympathetic tomboy, expresses no equanimity for Phil's behavoir.

Elle étendit une main vers le front de Philippe, et la retira avant le contact. La stupeur quitta son visage, où montèrent l'expression de la sévérité, une grimage amère et triste qui n'avait point d'âge, un mépris, tout viril, pour la faiblesse suspecte du garçon qui pleurait. (Le Blé, 114)

Mme. Dalleray treats Phil in somewhat of a dissimilar manner. She realizes that he is a young man, yet detects in his makeup a childlike sensibility. His sexual identity, like Vinca's, is similarly approached here. Mme. Dalleray calls him over to her by first labeling him "petit". When she notices his "torse nu" however, she changes her tone with him, blushes and calls him "monsieur" (Le Blé, 
52). Her second feeling of inconsistency towards Phil's manhood occurs in almost the same moment.

Prenez garde, je vais vous tutoyer : vous paraissez douze ans, quand vous riez. Mais elle le regardait dans les yeux, comme un homme. (Le Blé, 53)

Phil appears to fluctuate between his childhood and his adolescence: $\mathrm{He}$ is maturing both physically and mentally. So the stereotypes that he combats, both from external forces and internal forces, molds his sexuality.

Colette plays with the idea of gender even more while creating her character Vinca. Vinca's body is constantly related to that of a young boy. She is also refered to as Phil's fraternal "compagnon". Still, she has a "feminine" quality about her. Once in a while she talks to Phil in a very gentle manner.

Elle parlait avec une douceur sibylline, qu'il n'osa interroger davantage, et dont il n'osa se réjouir. Vinca le suivit sans doute dans son mouvement de repli mental, car elle ajouta subtilement:

--Tu te souviens des scènes que tu me faisais, et des miennes, il n'y a pas trois semaines, parce que nous nous impatientions d'avoir quatre ans, cinq ans à nous morfondre avant de nous marier? (Le Blé, 119)

Vinca's "douceur" depicts only one part of her personality: Usually, she emanates a masculine energy. She is young and still carving out her proper place in life. So, some of her social graces are not quite refined yet.

Elle le frappa soudain au visage d'un poing si imprévu et si garçonnier qu'il faillit tomber sur elle et se battre de bon coeur. Les paroles qu'elle venait de vociférer le 
retinrent et sa masculine et foncière décence recula devant ce que Vinca conprenait et faisait comprendre sans détours. (Le Blé, 159)

As much as Colette includes diverse social practices by these two protagonists they are not inherently related to either person's sexual development. There is no judgment placed on either one for displaying mannerisms outside of the norm, nor for looking a certain way. In fact, they maintain a sense of wholeness inside.

...Colette consistently sought the unity behind creation: "There is only one animal," she often said. Whatever the division--flora or fauna, male or female--Colette resisted imposed duality and embraced a vision of wholeness, which has much to offer contemporary students of androgyny. (20th Cent. Lit. Crit., 122)

Gender is constantly evolving inside of Colette's characters. It surfaces in her writing as a way to enrich the protagonist's identity. It places no meaning onto the differences in nature between men and women. It just adds definition to their personality.

In fact the social practices are not reflecting natural differences with these diacritical marks of gender. They are weaving a structure of symbol and interpretation around them, and often vastly exaggerating or distorting them. As Rubin observes, social emphasis on difference negates natural similarity. When we push further into the detail of the social arrangements about gender, it is striking how regularly denials, transformations and contradictions appear. Homosexual men are socially defined as effeminate, homosexual women as mannish; in fact there are no physical or physiological differences between homosexual and heterosexual people. (Connell, 80) 
Colette actualizes the notion of gender through Vinca's and Phil's personalities and bodies. Phil reacts negatively to the sight of Vinca's body. He believes that she is too masculine. "<<Comme elle est solide>> pensa-t-il, avec une sorte de crainte" (Le Blé, 110). It is then assumed that Vinca will do the same towards him for "crying like a woman." The conception of male and female roles is brought about in Phil and placed on Vinca. She cancels out his stereotypes by denying them. "La phrase enfantine laissa de l'espoir à Philippe, qui saisit le bras nu de son amie. -- Tu m'en veux, je sais bien, d'avoir pleuré comme une femme... -- non, pas comme une femme..." (Le Blé, 118). Colette seems to purposefully cover the gender agenda, even though she has never "...articulated a complete philosophical position on this or any other matter..." (Eisinger,122). This idea seems to just flow in her writings as it does in her characters, Phil and Vinca. All the same, the notion of gender does move from one level to another in Colette's works, dissipating and then reconstructing itself in differing forms.

Colette raises the issues of gender role reversal in La Chatte as she does in Le Blé en Herbe. However, she now moves to another plane of personal development in her protagonists. Her new characters are not as ambiguous as were the former.

It is Colette's inspiration to see androgyny not as "a static image of perfection," but as a dynamic series of life stages. The pattern of Colette's fiction can be seen as the journey of a "pure" protagonist away from the androgynous paradise of youth, through the impurity of rigid sex assignment, and back toward an ideal which unifies male and female (Eisinger, 122) 
In La Chatte, Camille and Alain's sexual identities are portrayed as extreme opposites. This is the 'in-between' period when a strict sex identity is created for Colette's characters. Camille is definitely more assertive than Phil, in terms of her personality and emotions.

Camille rougit et se dégagea, puis elle tendit sa joue à Alain avec une grâce si garçonnière et si fraternelle qu'il faillit se réfugier sur son épaule... (La Chatte, 17)

Camille is forward with Phil, so much so that he becomes intimidated and flustered by it. Their sexual roles in their relationship are reversed. The traditional male element of being in command is brought out in Camille and is something with which Phil can not cope. When Camille acts in such a manner, Phil retreats further into himself, portraying an even lower self-image than he normally has.

Embrasse-moi, supplia-t-elle tout bas, comme si elle lui demandait secours. Gauche, inquiet, et mal défendu sous son pyjama léger.... (La Chatte, 39)

What is then suspect in La Chatte, at this stage of the characters' feminine and masculine developments, seems to be the fact that Colette does not include a flowing masculine/feminine energy within the two protagonists. In other words, for Phil and Vinca in Le Blé en Herbe, there lingers some questions about their masculine and feminine personalities and body types. However, in La Chatte Alain and Camille are at opposite ends of the male/female scale and depict the reverse of the stereotypical roles: Their parts are clearly 
defined in terms of who is strong and the leader and who is weak and the follower.

For example, some women go to the opposite extreme of current social stereotypes. Rather than balancing and integrating their feminine energies with their masculine energies, they may virtually deny the feminine in themselves. A woman may reject traditional feminine roles in order to prove to men that she can play masculine roles. (Nicholson, 131)

Camille is outspoken and tough with Alain, so much so that she makes the decision that they will move into an apartment in the city. Thus, in this small and modern dwelling Camille lays out some rules for Alain and his cat Saha to follow. The neighbors comment on her authoritative behavoir as well.

La jeune dame de M. Alain prend bien bonne mine. Et elle a bonne voix aussi. On l'entend de chez nos voisins tant qu'elle parle bien. Une voix à ne pas la disputer, ah! mais...La jeune dame dit bien ce qu'elle veut dire. (La Chatte, 59)

Alain then notices her imperious attitude and predictably internalizes it. "Pourtant il lui sembla qu'elle le consultait sans parler, pour la première fois" (La Chatte, 60). Camille even dictates aloud what Alain should and should not do. "Empêche-la! criait-elle à Alain. Elle me tourne le coeur et elle me donne des crampes dans le mollets!" (La Chatte, 66). The role of being outspoken, bossy, and assertive is usually associated with men, but here it is magnified through Camille. "Fear equals femininity. To be fearful is to be a sissy. Masculinity means transcending fear" (Goldberg, 29). She typifies the male stereotype of being fearless and continues to 
behave similarly. "Camille éclata de rire comme si elle n'eût attendu que ce mot insultant. -. Peur?... Je n'ai pas peur de grandchose, moi, tu sais!" (La Chatte, 73). Women are typified as fragile and fearful, while men are brawny and brave.

Sex roles are expectations for behavior and attitudes that a particular culture defines as appropriate for men and women. Men and women learn their expected sex roles through the process of sex role socialization. This process has traditionally taught girls to particularly value being attractive, young, nonaggressive, nonathletic, emotionally expressive, tender, domestic, conciliatory, and nurturing. Through the same process, boys have been trained to value aggression, dominance, strength, emotional stoicism, adventure, athletic ability, achievement, goal attainment through conflict, and monetary success. (Whicker, 8)

It appears that Colette understands these roles and argues their validation in her work by disassociating Camille and Alain from the tradition.

Alain is from a secure and confortable world in which his overpowering mother figure controls his thoughts. She is an aristocrat who has created a matriarchal realm for her son.

Les Amparat ne sont plus dans la soie, la mère et le fils ont seulement conservé des intérêts dans la maison, et le fils n'y fait pas figure de maître.... (La Chatte, 37)

Again, when Alain and Camille split up, he returns to his mother's house to find homage. She was expecting him to come back, knowing that he and Camille were not of the same caliber.

-- S'il n'y a pas de draps à mon ancien lit, maman, je m'envelopperai dans n'importe quoi...--Il y a des draps à 
ton lit, dit Mme. Amparat. Sur ce mot il étreignit sa mère, l'embrassa en aveugle sur les yeux, sur les joues et les cheveux, lui poussa son nez dans le cou, bégaya $\ll<$ bonne nuit $>$ et sortit en reniflant. (La Chatte, 139)

What Alain finds back at home is a sympathetic mother who has already prepared his bed for his return. She knows that Alain is too fragile to reside with an overwhelmingly powerful woman other than herself. Even his physical description tells of his disposition.

Mais elle s'arrêta aux rudes cheveux blonds désordonnés, à la poitrine nue sous le pyjama, à la confusion qui colorait Alain, et tout son visage de jeune fille avoua si clairement la chaude indulgence d'une femme qu'Alain n'osa plus lui donner le baiser de midi moins le quart, celui du jardin ou du Bois. (La Chatte, 39)

The mother's home brings out Alain's childlike traits which help shape his person. He reverts to a stereotypically feminine behavior. He is manipulative and moody.

Alain jeta un éclat de rire enfantin, le rire qu'il gardait pour la maison et l'étroit intimité, qui ne franchissait pas la charmille d'ormes ni la grille noire. Puis il bâilla frénétiquement. (La Chatte, 19)

In his boyish state, his role shines through. He transforms himself into a powerless and delicate child. "...II redevenait faible, chimérique, attardé dans les rets d'une interminable et douce adolescence..." (La Chatte, 22). Alain reverts to his childhood behaviors and is comfortable with this role: This reinforces the concept of role reversal in La Chatte. "Just as ideal masculinity translates into militant independence, ideal femininity involves clinging dependency, helplessness..." (Goldberg, 25). Alain as well as 
Camille are polar opposites each defining their function in relation to one other. They are unable to coexist as such, so Camille, the stronger of the two, makes the final decision which is to depart and become the free-spirited traveler in search of her androgynous identity, her whole self.

La Vagabonde only has one primary character who searches out the true nature of her being. Renée Néré reflects on her childhood to discover herself, she becomes the vagabonde who cannot be denied her individual autonomy. Stereotypes fall into the abyss as Renée evaluates who she is, mostly through self-talk and looking at herself in the mirror. Once again, the gender topic is brought out through her personality and her body. However, this time as the crone-mother, Renée releases the past and the stigmas placed upon her, and she looks to her future without further entrapments.

Renée's search for androgyny infuses the setting, characterizations, plot, and imagery of La Vagabonde, none of which are rigidly sex-specific, and all of which promote role reversal or role transcendence. Each element of the novel's structure contributes to strengthening Renée's acceptance of her androgynous identity; each enlarges the protagonist's and the reader's conception of androgynous possibility. (Eisinger, 122)

The idea of gender takes on new meaning for Renée. Instead of living in an androgynous state like Phil and Vinca, who comprehend nothing of their own condition, Renée is moving towards an understanding of herself or an androgynous whole. She does not question her physical appearance in the same way the younger characters do: She is not concerned with her physical strength as she is with her aging face. 
Masculinity and femininity are now related with the lines on her face. She emerges as neither the masculine male nor the feminine female. She appears only as the old woman.

...je vais me trouver seule avec moi-même, en face de cette conseillère maquillée qui me regarde, de l'autre côté de la glace, avec de profonds yeux aux paupières frottées d'une pâte grasse et violâtre. Elle a des pommettes vives, de la même couleur que les phlox des jardins, des lèvres d'un rouge noir, brillantes et comme vernies... Elle me regarde longtemps, et je sais qu'elle va parler...Elle va me dire.... (La Vagabonde, 1)

It is not necessary for Renée to accept the conditions of the female role placed upon her because she is making her own decisions as to how to define her position in life. At this stage she is not willing to give up her privileges for a man who would constrict that right.

We cannot accurately speak of women and men in general. Each one of us is a human being before being 'man' or 'woman.' And each one of us, man or woman, has roles and functions to fulfill, individually, interindividually and socially. Here is where the differences being. These are most emphatically not differences in value, only differences in function. The human being is never defined by any of these roles. Woman, as human beings, can accept or not accept traditional feminine roles...It is not a 'must,' a necessity. It is free choice. (Nicholson, †28)

Renée makes several life changing choices; she divorces Taillandy; she works in a music-hall as a dancer; she allows a man to enter her life, though reluctantly; and finally she leaves on tour to gain her personal freedom. These reflections, all told to the 
reader in journal form, direct Renée towards a higher plane of consciousness. She begins to view herself as an androgynous form.

La Vagabonde illustrates Colette's concept of androgyny as prelapsarian, as a recollection of adolescent purity, to be renewed through the dual disciplines of work and solitude. (Eisinger, 122)

Both the ideas of work and solitude create this sexless person who stands alone in oneness with nature. Renée works in an field which men tend to dominate: They do not dominate the working environment, but they are the main reason her job exists. She is an object to them, one which performs in front of an audience.

Contrary to societal beliefs around her, she believes that the beauty she portrays comes not from her body; instead it emanates from her art. She incorporates her athletic abilities and her agility of: movement into one form. This produces the all encompassing male and female energy that she radiates.

Allons, allons! je suis trop lucide, ce soir, et si je ne me reprends, ma danse va en pâtir...Je danse, je danse... Un beau serpent s'enroule sur le tapis de Perse, une amphore d'Egypte se penche, versant un flot de cheveux parfumés, un nuage s'élève et s'envole, orageux et bleu, une bête féline s'élance, se replie, un sphinx, couleur de sable blond, allongé, s'accoude les reins creusés et les seins tendus... Je n'oublie rien, je me suis ressaisie. Allons, allons! Ces gens-là existent-ils?... Non, non, il n'y a de réel que la danse, la lumière, la liberté, la musique... II n'y a de réel que rythmer sa pensée, la traduire en beaux gestes. (La Vaga, 53)

There are several images of integrated masculine and feminine activity in Renée's performance, the most protuberant being that of 
the Sphinx. This unique being is defined as "A winged monster with a lion's body and a woman's head: It strangled passers-by unable to guess its riddle" (Webster's dictionary, 575). The creature is regarded as sexless which, in turn, is what Renée self actualizes during her dance.

Another major point brought out in the aformentioned passage is formalizing thought into action, which is changing from the passive into the active role. "Il n'y a de réel que rythmer sa pensée, la traduire en beaux gestes" (La Vaga, 54). Constant flow from one side of the spectrum to the other in sex roles is common for Renée.

Please keep in mind that androgynous individuals are neither exclusively feminine nor masculine in behavior. They are free to choose unstereotyped solutions to problems that arise in life. Such unstereotyped behavoir is a process-oriented solution rather than a roleoriented solution, which is limited by the traditional view of sex roles. (Forisha, 85)

Renée is very much a process-oriented character. She communicates through her journal which is her way of investigating life. This way, she can analyze and process through the matters happening around her.

Invulnérable, et pis qu'insensible: rétractile. Car, lorsque je donne la main à mon amoureux, le contact de sa longue main, chaude et sèche, me surprend et me déplaît...Je ne consentirais pas à nouer sa cravate, et j'aimerais mieux boire dans le verre de Hamond que dans le sien...Pourquoi?...ce garçon est un homme. Malgré moi, je me souviens qu'il est un homme. (La Vagabonde, 91) 
In this instance Renée does not want any physical contact with her 'lover' and she questions herself as to why. Simply because she is a woman, does not indicate that she will be attracted to all men at all times. Again, her role is constantly flowing from the passive into the active and vice-versa. She likes her lover Max but does not desire physical contact from him very often.

Both men and women are equally victims of sexual conditioning that puts their sexual needs together at cross-purposes. Frustration, disappointment, even disgust and a phobic attitude are the logical end points of traditional masculine-feminine conditioning. (Goldberg, 90)

The conditioning that fits the traditional male/female relationship does not connect with Renée's association with Max: She is ever so freely moving in her androgynous ideal as the vagabond. Not wanting to be with Max sexually has little to do with normal societal socialization. She already knows the concept of freedom because of leaving Taillandy behind and making a career move. So, to be or not to be with Max relates to her androgynous autonomy and not to her gender identity.

In dealing with the phenomenon of human sexuality, it must be kept in mind that many physiological, psychological, and behavioral factors are involved in a very complex interrelationship. (Vetterling-Braggin, 190)

Renée herself cannot fully understand the choices that she has made nor does she excuse them. She just lives in her complexity called life and finally moves beyond her past. 
The moment of Renée's departure on tour becomes the turning point for her. She can now be what is termed as an androgyn. In her first few letters she finds it difficult to let go of Max, but over time she is able to look to her own future and let him go.

N'oubliez pas que vous m'avez promis de m'écrire $<<$ tout le temps $>>$ et de consoler Fosette. Je vous promets, moi, de vous rapporter une Renée lasse de $<<$ tourner $>$, maigrie de solitude, et libre de tout, sauf de vous. (La Vagabonde, 195)

After realizing that she must break her link with Max, she travels within herself to a place beyond her own despair. It appears that Renée discovers her grief in the wilderness of the French countryside. It is at this place where she lies to rest most of her torment.

Une double allée harmonieuse monte vers la tour Mange entre les murailles ciselées d'ifs, et je me repose une minute au bord d'une auge de pierre, où l'eau ternie est verte de cresson fin et de rainettes bavardes aux petites mains délicates... Là-haut, tout en haut, un lit sec d'aiguilles nous reçoit, moi et mon tourment. (La Vaga, 225)

The outcome shapes Renée's future, it emphasizes solitude yet includes 'awareness'. Her rejection of Max is a disassociation with the patriarchy and social 'norms.' Hence, she ultimately sheds her gender classification. "To "escape from the prison of gender" is to reach the free land of humanity and personhood..." (VetterlingBraggin, 197). In the conclusion of La Vagabonde Renée chooses to leave, to escape from her prison. 
Car je te rejette, et je choisis... tout ce qui n'est pas toi. Je t'ai déjà connu, et je te reconnais. N'es-tu pas, en croyant donner, celui qui accapare? Tu étais venu pour partager ma vie... Partager, oui : Prendre ta part! Etre de moitié dans mes actes, t'introduire à chaque heure dans mes actes, de mes pensées, n'est pas? Pourquoi toi plutôt qu'un autre? Je l'ai fermée à tous. (La Vaga, 245)

Renée's second and final refusal of a male counterpart completes her life cycle and proposes a basic wholeness in her character.

Finally, the last topic to be analyzed and a common thread throughout Colette's works is her use of the female metamorphosis during angry moments. The female protagonists actually physically transform when impassioned. This is related to gender inasmuch as Colette is defining female sexuality in terms of animal behavior. At a certain point in Le Blé en Herbe while Vinca and Phil are arguing, Vinca turns passionately bestial.

Elle fit un cri d'oiseau irrité, perçant, imprévu, dont Philippe tressaillit...Elle s'était appuyée sur ses deux mains ouvertes, presque à quatre pattes, comme un animal. Il la vit soudain effrénée, empourprée de courroux. Ses deux panneaux de cheveux tendaient à se rejoindre sur sa figure penchée, et ne laissaient place qu'à sa bouche rouge et sèche, à son nez court élargi par un souffle coléreux, à ses deux yeux d'un bleu de flamme. (Le Blé en Herbe, 158)

Vinca's conduct goes beyond the male and female issue of gender, it enters the animal world. More specifically, the feline role, which is what Vinca is depicting, is often related to a intimately sexual woman whose behavior clearly depicts her desire. 
The feline attributes grow as does the maturity level of the characters in question. The adolescent girl Vinca is now described as a young woman named Camille. The story in La Chatte is about a cat, a man and his new bride. The cat breaks down the relationship between this man and woman. The woman, Camille, strives to stop this from happening. At the moment of Camille's attempt on the cat's life, Colette connects female gender to the feline world in a variable manner, unlike in Le Blé en Herbe. This time both the cat and Camille are reacting to each other as adversaries. Camille hunts Saha to the death only in a manner similar to that of the feline hunt. She chases and corners Saha and then pushes her off the balcony.

Saha s'était reprise, et fût morte plutôt que de jeter un second cri. Traquant la chatte sans paraître la voir, Camille alla, vint, dans un complet silence. Saha ne sautait sur le parapet que lorsque les pieds de Camille arrivaient sur elle, et elle ne retrouvait le sol du balcon que pour éviter le bras tendu qui l'eût précipitée du haut des neuf étages. (La Chatte, 113)

Colette mingles the female and the feline world during a moment of extreme madness for Camille. This gives her an animalistic fervor with which, when taken to the limit, she is even able to kill. Derived from this is the notion that she, like all humans, has animal instincts that arise when a breakdown in emotional control occurs.

The animal-like aspect of the human can be seen throughout history. Several theories have been revealed about the animal link to human nature. "Like Darwin and Briffault, Freud sees some clues to the nature of feminine and masculine in the animal world, though he is not certain this carries enough force..." (Vetterling-Braggin, 
17). It is through Colette however, that the peculiarities of the feline is best represented. Her final stage, that of the vagabond still alludes to the view that female vehemence transmutes into feline behavoir. This view is not unique to Colette, it is one of very old tradition.

Bast, the cat-mother of the city of Bubastis, was the benevolent aspect of Hathor, the Lioness. Festivals of Bast were joyful with music, dancing, jokes, and sexual rites. Her dark side was Hathor as the leonine Sphinx, Sekhmet (Greek Sakhmis), tearer and devourer of men. (Walker, 148)

In La Vagabonde, Renée meets with her friend Margot to discuss Renée's affairs. She makes a supposition as to what Margo will say: "Chatte échaudée, tu retourneras à la chaudière!" (La Vaga, 149). In this remark Renée indirectly categorizes herself as a cat who has learned a lesson and will not repeat the same error. This comes from the saying, "chat échaudé, craint l'eau froide." When one learns a lesson, one does not repeat the same mistake. It is clear that Colette understands the implications of the feline being related to women on a sexual level as well. The expression implies that Renée is like a cat in heat who is only looking for a sexual relationship. Both illusions create a new comprehension of the female gender. It disassociates women from their "normal" stereotype that they are effeminate and weak and allows them power.

Humans have a need to be classified differently than animals. However, Colette has a point in showing that feline characteristics 
can come out in humans. This adds strength to the notion that gender stereotyping is exactly what it means. It is a concept made up by society and has little to do with the genetic make-up of a person. Actions produced by Colette's characters are simply induced through their personalities. So each personnage has distinctive traits differing from the others. Even their bodies appear different to each unique mind picturing it.

In all, the issue of gender is well represented by the writer of the early twentieth century. Colette is one of the first to mark it as a prevalent topic of discussion. In relation to her work, gender highlights the way in which the characters relate to themselves first and to others second. The final novel, La Vagabonde, demonstrates the ideal form of gender which is androgyny. Through the three novels, Colette seems to bring about this notion but only after years of grappling with the main question of relationships, the-who am 1?-and only after the many trials and errors from discovering their diverse answers. Finally, Colette creates an androgynous whole not only for her characters but also for herself. She relays her issues to an audience, allowing the world to struggle with her and her questions, and ultimately answers them the best way possible. 


\section{CONCLUSION}

In her book The Difficulty of Loving, Margaret Crosland recapitulates the life of Colette using a few selected works written by Colette. She validates, in her own way, the concept that Colette's characters represent the life span of one single woman, Colette herself. In other words, through her writings, Colette has created an image of a heroine. This figure encompasses the idea of the emancipated modern women.

The rôle of a classic is surely not to teach readers what to do or think, but to show them a personal vision of the world and generally to enrich their lives. By an extraordinary chain of events and sheer hard work this is what Colette achieved. The school-girl with the long plait, the actress in front of her mirror, the journalist, the professional novelist, the beautician, the old lady who still made up her face carefully and tried to conceal her high forehead beneath her gray, blue- or mauvetinted curls: a succession of women who were one, each fascinating the other to such an extent that they-shecould live not in search of time lost, but outside it. And in so doing this composite, elusive woman, la femme cachée until the end, fascinates us. (Crosland, 261)

Colette began her career locked in a room as a slave, writing for someone else. When she was released, she realized her own potential as a writer. Her novels contain contemporary issues such as gender marginality, spatial conflicts or boundaries, and feminine consciousness. Colette's writing then, manifests fundamental principles about relationships because of these themes. 
Relationships, or the interaction between people, is presented as a challenge by Colette, simply because of the differing points of view related in her stories. Struggles allow Colette's characters to grow and learn about others as well as themselves. In the adolescent phase of life, the characters begin to discover the freedom of making choices. Whether good or bad, harmful or helpful, these young protagonists scarcely recognize the distinction in their actions. In young adulthood, her characters fight to be liberated from either patriarchal society and its rules or from an overbearing mother-figure. In both cases, independence is the desired outcome. Finally, in the stage of maturity, the "crone" has already gained an understanding of sovereignty, yet still seeks more knowledge concerning the development of the self. The protagonists reasoning behind this is to comprehend others through an understanding of oneself.

Colette reveals one lesson about relationships which is only accepted by the maturing woman. Colette points out, in La Vagabonde, the grief of being alone. The main character, Renée, has experienced the sadness of being lonely, but chooses not to marry her lover Max. It is only through self-evolution that she discovers a peace of mind and a sense of security.

"Becoming and staying aware of the working of their minds are vital to constructivist women's sense of wellbeing. Self-awareness aids them in setting the ground rules for their interaction with others and in selfdefinition. Constructivists seek to stretch the outer boundaries of their consciousness--by making the unconscious conscious, by consulting and listening to the 
self, by voicing the unsaid, by listening to others and staying alert to all the currents and undercurrents of life about them, by imagining themselves inside the new poem or person or idea that they want to come to know and understand. Constructivists become passionate knowers.... (Belenky, 141)

In summary, in chapter I, the concept of spatial boundaries is defined with the help of binary oppositions. The conflict of interest between the protagonists seems to be a common thread throughout Colette's three novels. They are sadly unable to relate to each other and defend or protect themselves by creating barriers in their space. Secondly, in chapter II, the standard misconception of women's placement in society is destroyed because of their portrayal by Colette. She aids in the birthing process of the modern woman. At every level of growth, from adolescence to maturity, her female protagonists ascertain power. They learn to make their own decisions and not regret them. In some instances they even reject the patriarchal realm around them, and as a solution, they leave their spouses.

The final chapter, chapter III, affirms Colette's understanding of the interaction between people; it also acknowledges her wisdom that self-love must come first in order to, later, give respect to others. The gender issue, one which she clearly defines in her works, connects the mind and body and indicates particular characteristics in the protagonists' behavior. However, Colette's philosophy is rooted in the idea that gender is only a part of the 
personality. It is not attributed to one's sex. Therefore, being male or being female does not shape Colette's characters' gender.

The topics of space, consciousness and gender produce one large field, identified as relationships or human interaction. Colette's writings, the web which link the lesser themes and formulate a "whole", portray the struggles that each individual faces when making the choice to share their life with another. "Do I want to be with you?", "How do I behave with you and you with me?", and "Can I love myself first?" are all questions that Colette poses in her novels and then tries to answer. Her outlook is modern for a woman writing in the early twentieth century. She touches upon the subject of human connection, a subject which is universal in litterature, only she does this with an uncommon twist. Colette is not a model waiting for the modern woman to recognize and typify her, but she is a heroine who has already passed on a gift. As the wise woman, she has also realized her own power and bequeathed it in the form of writing. 
Abrams, M. H. A Glossary of Literary Terms. New York: Holt Rinehart and Winston, Inc., 1988.

Bachelard, Gaston. La politique de l'Espace. Paris: Presses Universitaires de France, 1964.

Belenky, Mary Field. Women's Ways of Knowing. New York: Basic Books Inc., 1986.

Bethards, Betty. The Dream Book: Symbols for Self-Understanding. California: Inner Light Foundation, 1983.

Biolley-Godino, Marcelle. L'Homme-Objet chez Colette. Paris: Editions Klincksieck, 1972.

Brie, Germaine. Women Writers in France. New Jersey: Rutgers University Press, 1973.

Cocteau, Jean. "(Sidonie-Gabrielle) Colette." Twentieth-Century Litarary Criticism. 16 (1981): 163-164.

Colette. Le Blé en Herbe. 1923. Ed. Flammarion. Paris: GarnierFlammarion, 1969.

Colette. La Chatte. 1933. Ed. Hachette. Paris: Le Livre de Poche, 1960.

Colette. La Vagabonde. 1910. Ed. Albin Michel. Paris: Le Livre de Poche, 1969

Connell, R. W. Gender and Power. California: Stanford University Press, 1987.

Crossland, Margaret. Colette the Difficulty of Loving. New York: The Bobbs-Merrill Company,Inc., 1973. 
Crossland, Margaret. Women of Iron and Velvet. New York: Taplinger Publishing Company, 1976.

Davies, Margaret. "Colette (Sidonie-Gabrielle Colette)." Dictionary of Literary Biography. 65 (1988): 42-66.

Devor, Holly. Gender Blending. Bloomington: Indiana University Press, 1989.

Eisinger, Erica M. "(Sidonie-Gabrielle) Colette." Twentieth-Century Literary Criticism. 16 (1981): 121-125.

Evans, Martha Noel. Masks of Tradition. Ithaca: Cornell University Press, 1987.

Fisher, Claudine. "Solitude et Liberté: Dilemme de Colette Dans La Vagabonde." Proceedings of Pacific Northwest Council on Foreign Language. Ed. Walter C. Kroft. (1974): 212-216.

Flieger, Jerry Aline. Colette and the fantom subject of Autobiography. Ithaca: Cornell University Press, 1992.

Forde, Mariana. "Spatial Structures in La Chatte." The French Review 58 (1985): 360-364.

Forisha, Barbara Lusk. Sex Roles and Personal Awareness. New Jersey: General Learning Press, 1978.

Goldberg, Herb. The New Male Female Relationship. New York: William Morrow and Company, Inc., 1983.

Heilbrun, Carolyn G. A Recognition of Androgyny. New York: Alfred A. Knoff, Inc., 1973.

Hoeveler, Diane Long. Romantic Androgyny. University Park: The Pennsylvania State University Press, 1990.

Holmes, Diana. Colette. New York: St. Martin's Press, 1991. Jong, Erica. "(Sidonie-Gabrielle) Colette." Twentieth-Century Literary Criticism. 5(1981): 190-194. 
Jouve, Nicole Ward. Colette. Indiana: Indiana University Press, 1987.

Ketchum, Anne A. Colette ou La Naissance du Jour. Paris: Lettre Modernes Minard, 1968.

King, Adele. French Women Writers. New York: St. Martin's Press, 1989.

Ladimer, Bethany. "Moving Beyond Sido's Garden: Ambiguity in Three Novels by Colette." Romance Quarterly. 36 (1989): 153-67.

Lottman, Herbert. Colette. Boston: Little, Brown and Co., 1991.

Luke, Helen M. Woman Earth and Spirit. New York: The Crossroad Publishing Company, 1989.

Miller, Nancy K. Subject to Change. New York: Columbia University Press, 1988.

Nicholson, Shirley. The Goddess Re-Awakening. India: Theosophical Publishing House, 1989.

Ogden, C.K. Opposition. London: Indiana University Press, 1932.

O'Flaherty, Wendy Doniger. Women, Androgynes, and Other Mythical Beasts. Chicago: The University of Chicago Press, 1980.

Phelps, Robert. "(Sidonie-Gabrielle) Colette." Twentieth Century Literary Criticism. 16 (1981): 115.

Richardson, Joanna. Colette. New York: Franklin Watts, 1984.

Ruppreach, Nancy E. "Colette." Cyclopedia of World Authors II. 2 (1989): 359-360.

Sack, Robert David. Human Territoriality. London: Cambridge University Press, 1986.

Sankovitch, Tilde. French Women Writers and the Book. New York: Syracuse University Press, 1988. 
Vetterling-Braggin, Mary, ed. "Femininity", "Masculinity" and "Androgyny". USA: Rowman and Allanheld Publishers, 1982.

Walker, Barbara G. The Crone. San Francisco: HarperCollins Publishers, 1985.

Walker, Barbara G. The Woman's Encyclopedia of Myths and secrets. San Francisco: HarperCollins Publishers, 1983.

Webster's New World Dictionary. 1985 ed.

Whicker, Marcia Lynn and Jennie Jacobs Kronenfeld. Sex Role Changes. New York: Praeger publishers, 1986. 